\author{
CEZARY KABAŁA ${ }^{1 *}$, PRZEMYSŁAW CHARZYŃSKI ${ }^{2}$, JACEK CHODOROWSKI ${ }^{3}$, \\ MAREK DREWNIK ${ }^{4}$, BARTŁOMIEJ GLINA ${ }^{5}$, ANDRZEJ GREINERT ${ }^{6}$, PIOTR HULISZ ${ }^{2}$, \\ MICHAŁ JANKOWSKI ${ }^{2}$, JERZY JONCZAK ${ }^{7}$, BEATA ŁABAZ ${ }^{1}$, ANDRZEJ ŁACHACZ ${ }^{8}$, \\ MARIAN MARZEC ${ }^{9}$, ŁUKASZ MENDYK $^{5}$, PRZEMYSŁAW MUSIAŁ ${ }^{10}$, ŁUKASZ MUSIELOK $^{4}$,

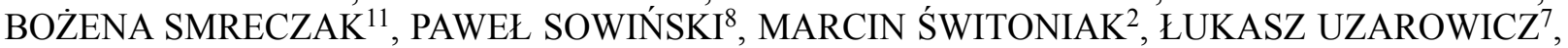 \\ JAROSŁAW WAROSZEWSKI ${ }^{1}$
}

\author{
${ }^{1}$ Wrocław University of Environmental and Life Sciences, Institute of Soil Science and Environmental Protection \\ ul. Grunwaldzka 53, 50-375 Wroctaw, Poland \\ ${ }^{2}$ Nicolai Copernicus University in Toruń, Faculty of Earth Sciences, Department of Soil Science and Landscape Management \\ ul. Lwowska 1, 87-100 Toruń, Poland \\ ${ }^{3}$ Maria Curie-Skłodowska University in Lublin, Department of Geology and Soil Science, ul. Kraśnicka 2cd, \\ 20-718 Lublin, Poland \\ ${ }^{4}$ Jagiellonian University, Institute of Geography and Spatial Management, Department of Pedology and Soil Geography \\ ul. Gronostajowa 7, 30-387 Kraków, Poland \\ ${ }^{5}$ Poznan University of Life Sciences, Department of Soil Science and Land Protection \\ ul. Szydłowska 50, 60-656 Poznań, Poland \\ ${ }^{6}$ University of Zielona Góra, Institute of Environmental Engineering \\ ul. Szafrana 15, 65-516 Zielona Góra, Poland \\ ${ }^{7}$ Warsaw University of Life Sciences - SGGW, Department of Soil Environment Sciences, \\ ul. Nowoursynowska 159, 02-776 Warsaw, Poland \\ ${ }^{8}$ University of Warmia and Mazury in Olsztyn, Department of Soil Science and Land Reclamation \\ Plac Łódzki 3, 10-727 Olsztyn, Poland \\ ${ }_{9}^{9}$ Bureau for Forest Management and Geodesy \\ ul. Piastowska 9, 49-300 Brzeg, Poland \\ ${ }^{10}$ Bureau for Forest Management and Geodesy \\ ul. Leśników 21, Sękocin Stary, 05-090 Raszyn, Poland \\ ${ }^{11}$ Institute of Soil Science and Plant Cultivation \\ ul. Czartoryskich 8, 24-100 Puławy, Poland
}

\title{
Polish Soil Classification, 6th edition - principles, classification scheme and correlations
}

Abstract: The sixth edition of the Polish Soil Classification (SGP6) aims to maintain soil classification in Poland as a modern scientific system that reflects current scientific knowledge, understanding of soil functions and the practical requirements of society. SGP6 continues the tradition of previous editions elaborated upon by the Soil Science Society of Poland in consistent application of quantitatively characterized diagnostic horizons, properties and materials; however, clearly referring to soil genesis. The present need to involve and name the soils created or naturally developed under increasing human impact has led to modernization of the soil definition. Thus, in SGP6, soil is defined as the surface part of the lithosphere or the accumulation of mineral and organic materials permanently connected to the lithosphere (through buildings or permanent constructions), coming from weathering or accumulation processes, originated naturally or anthropogenically, subject to transformation under the influence of soilforming factors, and able to supply living organisms with water and nutrients. SGP6 distinguishes three hierarchical categories: soil order (nine in total), soil type (basic classification unit; 30 in total) and soil subtype (183 units derived from 62 unique definitions; listed hierarchically, separately in each soil type), supplemented by three non-hierarchical categories: soil variety (additional pedogenic or lithogenic features), soil genus (lithology/parent material) and soil species (soil texture). Non-hierarchical units have universal definitions that allow their application in various orders/types, if all defined requirements are met. The paper explains the principles, classification scheme and rules of SGP6, including the key to soil orders and types, explaining the relationships between diagnostic horizons, materials and properties distinguished in SGP6 and in the recent edition of WRB system as well as discussing the correlation of classification units between SGP6, WRB and Soil Taxonomy.

Keywords: soil classification, soil order, soil type, soil origin, World Reference Base, Soil Taxonomy 


\section{INTRODUCTION}

Transformation of soils, progress in soil science and changing socio-economic conditions are major driving forces for the changes in soil classification, if the classification is to be understood as a modern reflection of current knowledge about soils and their functions in the natural environment and for human life (Arnold 2002). Therefore, every classification of soils, including the Polish Soil Classification, must be regularly verified and improved (Brevik et al. 2016). At the same time, it should not be forgotten that the classification system, and in particular the terminology used, reflects local scientific traditions, which should not be abandoned hastily (Krasilnikov et al. 2009). The sixth edition of the Polish Soil Classification (Systematyka gleb Polski 2019, later cited in an abbreviated form as SGP6), developed by the Commission for Soil Genesis, Classification and Cartography of the Soil Science Society of Poland, attempts to fulfill the abovementioned mission and expectations of different groups of professional users. SGP6 continues the tradition of previous editions of soil classification, in particular its fifth edition (Systematyka gleb Polski 2011), in the aspect of consistent application of precisely and quantitatively characterized diagnostic horizons, properties and materials. Quantitative clarification and digitization of classification criteria do not mean giving up the traditions of genetically oriented soil science. All classification units in SGP6 were determined in accordance with their genesis; some were even intentionally separated to emphasize the impact of various pathways of soil development (soil-forming processes) on their present morphology, properties and functions, even if it is not explicitly stated in the classification criteria.

The aim of this paper is to explain the principles and classification scheme of the Polish Soil Classification, $6^{\text {th }}$ edition (Systematyka gleb Polski 2019). The correlations of diagnostic horizons, materials and properties as well as classification units at various levels with WRB (IUSS Working Group WRB 2015, later cited in an abbreviated form as WRB2015) and Soil Taxonomy (Soil Survey Staff 2014, cited in an abbreviated form as ST2014) is also given and briefly explained to indicate the close relationships between modern Polish soil classification and major international systems.

\section{THE OBJECT OF CLASSIFICATION}

The soil definition often depends on the requirements for which this definition and related classifica- tion are made (Ibanez and Boixadera 2002). For many experts, the concept of soil was defined through the needs of agricultural and forest productivity (i.e. the usefulness for growing plants). Another perspective comes from an ecological approach, where soil can be a basis for every ecosystem, both naturally developed and human made, including those ecosystems considered unproductive or degraded (Jankowski and Bednarek 2000, Krupski et al. 2017, Musielok et al. 2018). Based on an ecological approach, it is very difficult, if at all possible, to determine the minimum soil contour area (or soil volume), if only cubic centimeters or decimeters of regolith accumulated in a rock crevice may create the basis for unique natural ecosystems (Miechówka and Drewnik 2018; Skiba and Komornicki 1983). In this context, questions are increasingly asked about the soils of ecosystems artificially created by humans or created by natural forces in an environment that has been substantially altered or created by man; for example, soils of road or railway embankments, earth covers on bunkers and other constructions, on green roofs, in niches on buildings and ruins filled with "anthropogenic regolith" etc. (Charzyński et al. 2013a, 2013b, 2015; Uzarowicz et al. 2017, 2018). In all these ecosystems, there are similar minerals that build natural soils, similar microorganisms enabling the circulation of matter and energy flow typical for soils, as well as enabling plant growth and soil fauna occurrence. Therefore, these are soils that build self-functioning ecosystems and which are relatively stable in time and space. However, not each accumulation of soil material lasts and functions as described above; for example, an earthy material accidentally accumulated on tractor wheels and on agricultural machinery or growing substrate on greenhouse benches (tables) or in pots on the windowsill. Therefore, in the Polish Soil Classification (SGP6), soil is defined as the surface part of the lithosphere or the accumulation of mineral and organic materials permanently connected to the lithosphere by buildings or permanent constructions, coming from weathering or accumulation processes, originated naturally or anthropogenically, subject to transformation under the influence of soil-forming factors, and able to supply the living organisms with water and nutrients.

\section{DIAGNOSTIC HORIZONS, MATERIALS AND PROPERTIES}

The Polish Soil Classification, since its fourth edition (1989), is based on soil features, being the combined results of soil-forming factors and processes, defined in terms of diagnostic horizons, diagnostic 
materials and diagnostic properties, all of which to the highest possible extent should be observable and measurable in the field. General concepts and detailed criteria for many diagnostic horizons/materials/properties are taken from WRB2015. However, original Polish concepts, not reflected in an international soil classification, or local specific features of soil cover have led to adding a number of unique diagnostic horizons/materials and changing detailed criteria in the original definitions of many others. To avoid misunderstanding and incorrect classification (correlation), the names of all diagnostic horizons, materials and properties have changed spelling, mainly by replacing the standard ending "-ic" with "ik". All diagnostic horizons, materials and properties defined in Polish Soil Classification, along with brief explanation of their relationships with WRB2015, are listed in tables $1-3$.
The criteria for diagnostic horizons/materials/properties generally are not fully disjunctive; however, horizons that have similar characteristics differ in at least one disjunctive, restrictive or exclusive criterion, which refers to the specific impacts of pedogenic factors or processes, creating a unique theoretical basis for a given diagnostic horizon. A separate key to diagnostic horizons has not been prepared, but the general key to soil orders and soil types (table 4) clearly indicates the order of analysis/elimination of diagnostic horizons, i.e. suggests which criteria should be taken into account first. In a case of humus-rich dark-coloured topsoil horizon this means for example, that first to be checked are the criteria for histik/murszik/folik horizons (the order of organic soils is placed first in the key), then for hortik/antrik (anthropogenic soils are placed on the second position in the key) and finally for arenimurszik/mollik/umbrik. Similarly, in

TABLE 1. The relationships between diagnostic horizons in Polish Soil Classification (SGP6) and WRB2015

\begin{tabular}{|c|c|}
\hline SGP6 & Relation to WRB 2015 \\
\hline albik & $\begin{array}{l}\text { no equivalent; criteria like for albic material; refers to } \mathrm{Fe}, \mathrm{Al} \text { and humus depletion (result of podzolization): } \geq 50 \% \text { of } \\
\text { sand grains free of (Fe-)humus coatings; thickness } \geq 1 \mathrm{~cm}\end{array}$ \\
\hline antrik & $\begin{array}{l}\text { no equivalent; criteria like for anthric properties; phosphorus limits refer to citric acid and Mehlich } 3 \text { tests (Kabała et } \\
\text { al. 2018); thickness } \geq 30 \mathrm{~cm}\end{array}$ \\
\hline arenimurszik & $\begin{array}{l}\text { no equivalent; criteria like for mollic/umbric (thickness, organic carbon content, colour), but sandy texture and weak } \\
\text { binding of mineral fraction and particles of organic matter( } \geq 10 \% \text { of sand particles has no humus coatings; organic } \\
\text { matter easily separates from sand grains at soil grinding in dry state); often derived by drainage and mixing (ploughing) } \\
\text { of histik/murszik horizons with underlying sandy subsoil (Łabaz and Kabała 2016) }\end{array}$ \\
\hline argik & $\begin{array}{l}\text { like argic, excluding criterion } 2 \mathrm{~b} \text { (texture differentiation without visible clay coatings); required } \geq 20 \% \text { clay } \\
\text { bridging/coatings }\end{array}$ \\
\hline eluwik & $\begin{array}{l}\text { no equivalent; criteria like for albic material; refers to clay depletion (result of eluviation/lessivage): sand particles free } \\
\text { of clay coatings and bridges, no coatings on structural eggergates, lower clay content compared to underlying horizon; } \\
\text { thickness } \geq 1 \mathrm{~cm}\end{array}$ \\
\hline folik & like folic \\
\hline histik & like histic, but organic material requires $\geq 12 \%$ of organic carbon \\
\hline hortik & $\begin{array}{l}\text { like hortic, but required thickness } \geq 30 \mathrm{~cm} \text { and required } \mathrm{pH}_{\mathrm{w}} \geq 5.5 \text { (instead of base saturation } \geq 50 \% \text { ); phosphorus } \\
\text { limits refer to Olsen and Mehlich } 3 \text { tests (Kabała et al., 2018) }\end{array}$ \\
\hline kalcik & $\begin{array}{l}\text { like calcic, excluding criteria } 2 \mathrm{~b} \text { (relative difference of } \mathrm{CaCO}_{3} \text { content in comparison to underlying layer) and } \\
3 \text { (petrocalcic) }\end{array}$ \\
\hline kambik & $\begin{array}{l}\text { like cambic, but sandy texture classes are excluded; larger presence of clay bridges/coatings is allowed } \\
(<20 \% \text {, complementary to argik) }\end{array}$ \\
\hline mollik & like mollic, but required thickness $\geq 30 \mathrm{~cm}$ and required $\mathrm{pH}_{\mathrm{w}} \geq 5.5$ (instead of base saturation $\geq 50 \%$ ) \\
\hline murszik & $\begin{array}{l}\text { no equivalent; criteria like for histic horizon with additional requirements like for murshic qualifier; refers to peat } \\
\text { degradation due to drainage and further pedogenic transformation (including humification and structure development) }\end{array}$ \\
\hline rubik & $\begin{array}{l}\text { no equivalent; refers to } \mathrm{Fe}(+\mathrm{Mn}) \text { subsurface precipitation at the contact of groundwaters of different origin; criteria } \\
\text { similar to rubic qualifier, but hue redder than } 7.5 \mathrm{YR} \text { (and redder than parent material) and chroma } \geq 5 \text {; thickness } \geq 15 \mathrm{~cm}\end{array}$ \\
\hline siderik & $\begin{array}{l}\text { no equivalent; considered an analogue to cambic horizon, but developed in sandy texture classes (criteria like for } \\
\text { brunic qualifier); a Munsell colours } 7.5 \mathrm{YR} \text { or } 10 \mathrm{YR} \text {, value } 4-6 \text { and chroma } \geq 3 \text { moist are required (if parent material } \\
\text { has above mentioned colours, siderik has redder hue and/or higher chroma and/or lower colour value than parent } \\
\text { material); thickness } \geq 15 \mathrm{~cm}\end{array}$ \\
\hline spodik & like spodic \\
\hline umbrik & like umbric, but required thickness $\geq 30 \mathrm{~cm}$ and $\mathrm{pH}_{\mathrm{w}}<5.5$ (instead of base saturation $<50 \%$ ) (Kabała and Łabaz 2018) \\
\hline wertik & like vertic \\
\hline
\end{tabular}


TABLE 2. The relationships between diagnostic properties in SGP6 and WRB 2015

\begin{tabular}{|c|c|c|}
\hline SGP6 & $\begin{array}{l}\text { English } \\
\text { translation }\end{array}$ & Relation to WRB2015 \\
\hline fragipan & fragipan & like for fragic horizon, but no thickness requirements \\
\hline geomembrana & geomembrane & $\begin{array}{l}\text { no equivalent; synthetic membrane covering soil surface or dividing soil layers, impermeable or } \\
\text { hardly permeable to water and gas }\end{array}$ \\
\hline $\begin{array}{l}\text { gtębokie } \\
\text { wymieszanie }\end{array}$ & deep mixing & $\begin{array}{l}\text { no equivalent; deep ( } \geq 50 \mathrm{~cm} \text { ) mixing of soils (destruction of soil horizonation, fragments of } \\
\text { horizons translocated within soil profile etc.), due to (1) very deep cultivation (ploughing), } \\
\text { or (2) construction works; sharp lower boundary; soil surface typically not elevated }\end{array}$ \\
\hline lamelle & lamellae & like for lamellic qualifier, but thickness criteria moved to subtype requirement \\
\hline lita skata & $\begin{array}{l}\text { continuous } \\
\text { rock }\end{array}$ & like continuous rock, but cracks occupy $<5 \%$ of the cross section \\
\hline $\begin{array}{l}\text { lita warstwa } \\
\text { technogeniczna }\end{array}$ & $\begin{array}{l}\text { technogenic } \\
\text { hard layer }\end{array}$ & like technic hard material \\
\hline $\begin{array}{l}\text { nieciagłość } \\
\text { litogeniczna }\end{array}$ & $\begin{array}{l}\text { lithogenic } \\
\text { discontinuity }\end{array}$ & $\begin{array}{l}\text { like lithic discontinuity, but textural differentiation resulting from alluvial and colluvial } \\
\text { sedimentation is excluded }\end{array}$ \\
\hline orsztyn & ortstein & like ortsteinic qualifier \\
\hline placik & placic & like placic qualifie \\
\hline ruda darniowa & bog iron & $\begin{array}{l}\text { like for ferric horizon, but Fe-Mn-nodules form }>20 \% \text { of a layer volume and criteria } 1 \text { a (mottles) } \\
\text { and } 2 \text { (relations to plinthic) are not considered }\end{array}$ \\
\hline $\begin{array}{l}\text { wtaściwości } \\
\text { gruntowo-glejowe }\end{array}$ & $\begin{array}{l}\text { gleyic } \\
\text { properties }\end{array}$ & like gleyic properties \\
\hline $\begin{array}{l}\text { wtaściwości } \\
\text { opadowo-glejowe }\end{array}$ & $\begin{array}{l}\text { stagnic } \\
\text { properties }\end{array}$ & like stagnic properties \\
\hline zasolenie & salinity & $\begin{array}{l}\text { no equivalent; like for salic horizon, but required } \mathrm{EC}_{\mathrm{e}} \geq 4 \mathrm{dS} \mathrm{m}^{-1} \text {, and } \mathrm{pH}_{\mathrm{e}}<8.5 \text {, and } \mathrm{SAR}_{\mathrm{e}}<13 \\
\text { or ESP }<15 \%\end{array}$ \\
\hline $\begin{array}{l}\text { zasolenie } \\
\text { z sodyfikacja }\end{array}$ & $\begin{array}{l}\text { salinity with } \\
\text { sodification }\end{array}$ & $\begin{array}{l}\text { no equivalent; like for salic horizon, but required } \mathrm{EC}_{\mathrm{e}} \geq 4 \mathrm{dS} \mathrm{m}^{-1} \text {, and } \mathrm{pH}_{\mathrm{e}} \geq 8.5 \text {, and } \mathrm{SAR}_{\mathrm{e}} \geq 13 \\
\text { or ESP } \geq 15 \%\end{array}$ \\
\hline sodyfikacja & sodification & $\begin{array}{l}\text { no equivalent; like for salic horizon, but required } \mathrm{EC}_{\mathrm{e}}<4 \mathrm{dS} \mathrm{m}{ }^{-1} \text {, and } \mathrm{pH}_{\mathrm{e}}<8.5 \text {, and } \mathrm{SAR}_{\mathrm{e}} \geq 13 \\
\text { or } \mathrm{ESP} \geq 15 \%\end{array}$ \\
\hline $\begin{array}{l}\text { zaciekowość } \\
\text { eluwialna }\end{array}$ & $\begin{array}{l}\text { eluvial } \\
\text { tonguing }\end{array}$ & like retic properties (including albeluvic glossae) \\
\hline $\begin{array}{l}\text { zakwaszenie } \\
\text { siarczanowe }\end{array}$ & $\begin{array}{l}\text { sulfate } \\
\text { acidification }\end{array}$ & $\begin{array}{l}\text { like for thionic horizon, but additionally colours of discontinuous accumulations are specified } \\
\text { (hue } 2.5 \mathrm{Y} \text { or more yellow and chroma } \geq 6 \text { ) }\end{array}$ \\
\hline
\end{tabular}

TABLE 3. The relationships between diagnostic materials in SGP6 and WRB 2015

\begin{tabular}{|c|c|c|}
\hline SGP6 & $\begin{array}{l}\text { English } \\
\text { translation }\end{array}$ & Relation to WRB 2015 \\
\hline $\begin{array}{l}\text { materiat } \\
\text { organiczny }\end{array}$ & $\begin{array}{l}\text { organic } \\
\text { material }\end{array}$ & $\begin{array}{l}\text { like organic material, but in materials saturated with water for } \geq 30 \text { consecutive days in most } \\
\text { years, or drained, } \geq 12 \% \mathrm{C}_{\text {org }} \text { is required, while in materials saturated with water for }<30 \text { days } \\
\geq 20 \% \mathrm{C}_{\text {org }} \text { is required }\end{array}$ \\
\hline $\begin{array}{l}\text { materiat } \\
\text { mineralny }\end{array}$ & $\begin{array}{l}\text { mineral } \\
\text { material }\end{array}$ & $\begin{array}{l}\text { like mineral material, but in materials saturated with water for } \geq 30 \text { consecutive days in most } \\
\text { years }<12 \% \mathrm{C}_{\text {org }} \text { is required and in materials saturated with water for }<30 \text { days in most years } \\
<20 \% \text { Corg is required }\end{array}$ \\
\hline \multicolumn{3}{|l|}{ torfy (peats) } \\
\hline torf fibrowy & fibric peat & $\begin{array}{l}\text { criteria for recognizable plant tissue like for fibric qualifier, thickness/depth criteria specified in } \\
\text { subtype definitions }\end{array}$ \\
\hline torf hemowy & hemic peat & $\begin{array}{l}\text { criteria for recognizable plant tissue like for hemic qualifier, thickness/depth criteria specified in } \\
\text { subtype definition }\end{array}$ \\
\hline torf saprowy & sapric peat & $\begin{array}{l}\text { criteria for recognizable plant tissue like for sapric qualifier, thickness/depth criteria specified in } \\
\text { subtype definitions }\end{array}$ \\
\hline \multicolumn{3}{|c|}{ materiały limniczne (limnic materials) } \\
\hline gytia organiczna & organic gyttja & $\begin{array}{l}\text { no equivalent; meets the general criteria for limnic materials, contains } \geq 12 \% \text { of organic carbon } \\
\text { and }<20 \% \text { of } \mathrm{CaCO}_{3} \text {; resilient in a moist state (able to spring back into shape after being } \\
\text { compressed); cracking along horizontal planes after drainags }\end{array}$ \\
\hline
\end{tabular}


Table 3 continued

\begin{tabular}{|c|c|c|}
\hline gytia weglanowa & $\begin{array}{l}\text { calcareous } \\
\text { gyttja }\end{array}$ & $\begin{array}{l}\text { no equivalent; meets the general criteria for limnic materials, contains } \geq 12 \% \text { of organic carbon } \\
\text { and } \geq 20 \% \text { of } \mathrm{CaCO}_{3} \text {; weak resilience in a moist state; cracking along horizontal planes after } \\
\text { drainage }\end{array}$ \\
\hline wapień tdkowy & $\begin{array}{l}\text { meadow } \\
\text { limestone } \\
\text { (marl) }\end{array}$ & $\begin{array}{l}\text { no equivalent; meets the general criteria for limnic materials, contains }<12 \% \text { of organic carbon } \\
\text { and } \geq 20 \% \text { of } \mathrm{CaCO}_{3}\end{array}$ \\
\hline mut limnetyczny & $\begin{array}{l}\text { lacustrine } \\
\text { mud }\end{array}$ & $\begin{array}{l}\text { no equivalent; similar to limnic material (sedimentary peat) - sedimented in ponds, shallow lakes } \\
\text { etc.; contains } \geq 12 \% \text { of organic carbon, meets the criteria of sapric qualifier but may contain } \\
\text { lenses/layers of undecomposed plant residues, no evidences of resilience typical for gyttja }\end{array}$ \\
\hline mut telmatyczny & telmatic mud & $\begin{array}{l}\text { no equivalent; similar to limnic material (sedimentary peat) - sedimented in seasonally flooded wet } \\
\text { valleys; contains } 12-25 \% \text { of organic carbon, meets the criteria of sapric qualifier excluding the } \\
\text { roots and wood fragments, colour value } \geq 2 \text { and chroma } \geq 2 \text { moist, typically contains easily } \\
\text { recognizable admixture (layers, lenses etc.) of mineral fractions, no evidences of resilience typical } \\
\text { for gyttja }\end{array}$ \\
\hline \multicolumn{3}{|c|}{ materiaty antropogeniczne (antrophogenic materials) } \\
\hline artefakty & artefacts & $\begin{array}{l}\text { like artefacts; additional distinction is made between normal artefacts and reactive artefacts } \\
\text { (construction lime, ash and slag from metal smelting and coal burning, tailings, mining wastes } \\
\text { containing sulfides and native sulfur, phosphogypsum, petrochemistry wastes, chemical industry } \\
\text { wastes, bones etc.) }\end{array}$ \\
\hline $\begin{array}{l}\text { gtęboki materiat } \\
\text { nasypany }\end{array}$ & $\begin{array}{l}\text { thick heap } \\
\text { material }\end{array}$ & $\begin{array}{l}\text { no equivalent, but similar to transportic qualifier; loose, earthen material (may contain skeletal } \\
\text { fraction), having }<20 \% \text { of artefacts (or }<10 \% \text { of reactive artefacts), forming an intentionally } \\
\text { constructed layer } \geq 50 \mathrm{~cm} \text { thick (either an above-ground heap or below-ground infilling); the } \\
\text { following expression of intentional heaping is required: sharp or distinct boundary to underlying } \\
\text { native material, or underlying material contains artefacts (e.g. ash or construction rubble), or forms } \\
\text { a mound (embankment, etc.) } \geq 150 \mathrm{~cm} \text { high }\end{array}$ \\
\hline \multicolumn{3}{|c|}{ inne materiaty mineralne (other mineral materials) } \\
\hline $\begin{array}{l}\text { materiat } \\
\text { deluwialny }\end{array}$ & $\begin{array}{l}\text { colluvial } \\
\text { material }\end{array}$ & $\begin{array}{l}\text { like colluvic material, but limited to sediments accumulated in course of slope wash (sheet } \\
\text { erosion), whereas landslides and other mass movements are excluded (as well as an eolian, fluvial } \\
\text { and anthropogenic accumulation); (a) the following evidences of slope wash and accumulation are } \\
\text { required: favourable location (foot slope, accumulation trap, ravine outlet etc.), or buried organic } \\
\text { or humus layer, or lithogenic discontinuity in the contact with native soil; and (b) one or more of } \\
\text { the following is required: irregular vertical changes in organic carbon content (at } \geq 0.2 \% \text { organic } \\
\text { carbon in at least one of the layers), or homogeneous content of organic carbon ( } \geq 0.2 \% \text { ) } \\
\text { throughout the layer that overlies buried organic or humus horizon, or stratification or } \\
\text { sedimentation structures are present }\end{array}$ \\
\hline \multicolumn{3}{|c|}{ materiat fluwialny fluvic material like fluvic material } \\
\hline $\begin{array}{l}\text { materiat } \\
\text { gruboszkieletowy }\end{array}$ & $\begin{array}{l}\text { coarse-skeletic } \\
\text { material }\end{array}$ & $\begin{array}{l}\text { no equivalent; contains }>60 \% \text { (vol.) of skeletal fragments ( }>2 \mathrm{~mm} \text { in diameter) and has }>35 \% \\
\text { (vol.) of stones or coarser rock fragments }\end{array}$ \\
\hline $\begin{array}{l}\text { materiat } \\
\text { siarczkowy }\end{array}$ & $\begin{array}{l}\text { sulfidic } \\
\text { material }\end{array}$ & $\begin{array}{l}\text { like hypersulfidic material, but seasonal or permanent waterlogging is required, and the inorganic } \\
\text { sulfidic sulfur content is replaced with a ratio of organic carbon to total sulfur } \geq 20\end{array}$ \\
\hline
\end{tabular}

case of subsurface diagnostic B horizons, the order of analysis/elimination, related to the key to soil orders and types, is as follows: spodik, rubik, siderik, kambik.

One of crucial differences between SGP6 and WRB2015 is the required organic carbon content in the organic materials. In soils saturated with water for $>30$ consecutive days in most years (or drained) $\geq 12 \%$ of organic carbon was established at a sufficiently high to enable ecosystem services typical for organic soils (Piaścik and Łachacz 1990). In soils saturated for less than 30 consecutive days per year, the required organic carbon content is $\geq 20 \%$, similar to that for WRB2015 (table 3). This difference influ- ences the definition of the histik horizon (table 1) and soil allocation to order and type in the key, in particular the distinction between Histosols and Histic Gleysols (table 4). The other differences in diagnostic horizons are as follows:

- the mollik and umbrik (and also antrik and arenimurszik) horizons must be $\geq 30 \mathrm{~cm}$ thick (compared to $\geq 20 \mathrm{~cm}$ in WRB2015) that prevents an involvement of many normally ploughed soils into chernozemic soils,

- the argik horizon requires higher content of clay coatings/bridgings $(\geq 20 \%$ instead of $\geq 5 \%$ in WRB2015) that also influences the wider reco- 
gnition of kambik horizon and enables a transitional form of kambik with more prominent clay illuviation (Bwt horizon),

- the albik and eluwik horizons are distinguished instead of albic materials (WRB2015) to reflect pedogenic depletion of $\mathrm{Fe} / \mathrm{Al} / \mathrm{humus}$ and clay fraction in these horizons, respectively,

- the murszik horizon is (traditionally in Poland) separately distinguished from histik to reflect pedogenic transformation after drainage, including the development of pedogenic structure in organic horizons (Marcinek and Spychalski 1998; Piaścik and Gotkiewicz 2004; Piaścik and Łachacz 1990; Rząsa 1963),

- the arenimurszik horizon is a kind of mineral, sandtextured mollik or umbrik horizons, separately distinguished to reflect very weak binding of organic matter particles to mineral (sand) grains in topsoil layers developed mostly by advanced degradation of murszik horizons (Labaz and Kabala 2016),

- rubik horizon is a kind of subsurface horizon of $\mathrm{Fe}$ (and $\mathrm{Mn}$ ) accumulation at the contact of various kinds of ground waters, featured by red colours (Jankowski 2013),

- siderik is considered the sandy equivalent for the kambik horizon; it may be easily correlated with a Brunic qualifier in WRB2015 (Bednarek 1991). Many diagnostic properties distinguished in SGP6 (table 2) have the same or very similar definitions to their equivalents in WRB2015, in particular stagnic and gleyic properties. A number of properties in SGP6 have in WRB2015 close equivalents in diagnostic materials (e.g. lita skata/continuous rock, lita warstwa technogeniczna/technic hard material), or in diagnostic horizons (e.g. ruda darniowa/ferric (Czerwiński and Kaczorek 1996), fragipan/fragic (Szymański et al. 2011), zasolenie/salic, zakwaszenie siarczanowe/thionic (Hulisz 2007, Hulisz et al. 2017)), or in qualifiers (lamellic, ortsteinic, placic). SGP6 provides unique definitions for geomembrane and deep mixing (in situ), both applied to classify the techno-genic soils (table 2). Also, numerous specific diagnostic materials, besides the materials similar to those present in WRB2015 (table 4), are distinguished in SGP6:

- the terms fibrik, hemik and saprik are applied to peats only as for primary organic materials,

- gyttja (Łachacz et al. 2009), lacustrine and telmatic organic muds (Kalisz and Łachacz 2008; Mendyk et al. 2015, Okruszko 1969, Roj-Rojewski and Walasek 2013), and meadow limestone/marl (Jarnuszewski and Meller 2018) are distinguished among limnic matterials,
- thick heap material (gtęboki materiat nasypany) is a soil layer $\geq 50 \mathrm{~cm}$ thick, poor in artefacts, intentionally displaced/transported to create the convex relief form (e.g. dam, road/railway embankment etc.), or to fulfil the concave form, or to level the ground surface (Charzyński et al. 2013b),

- artefacts have been distinguished into "normal" (for example concrete and stones) and "reactive" (e.g. ash, slag, tailings), to reflect their different reactivity and toxicity in soil environments (Charzyński et al. 2013a, Uzarowicz et al. 2017), - coarse skeletic material reflects the specific composition of many mountain soils, influenced by weathering, denudation and slope processes (Drewnik 2008, Kacprzak et al. 2006, 2013; Skiba and Komornicki 1983),

- colluvial material (materiat deluwialny) has a definition related to the results of surface wash (sheet erosion) accelerated mainly by humans (due to removal of native vegetation and ploughing) and not to the landslides, creep and other slope mass movement/wasting (Świtoniak 2014, 2015).

\section{CLASSIFICATION SCHEME}

The SGP6 is a scientific system of soil units' allocation, hierarchical at the higher level of classification, and non-hierarchical (optional) at a lower level. There are three hierarchical categories in SGP6: soil order, soil type and soil subtype, supplemented by three non-hierarchical categories: soil variety, soil genus and soil species. Hierarchical units have a strict affiliation (allocation) to higher-order units and individual (unique) definitions, i.e. sets of requirements/ criteria. Non-hierarchical units, on the other hand, are in the majority not assigned to particular higherorder units, but due to their universal definitions, they can be added to any order, type or subtype, if all the criteria listed in their definitions are met. Soil subtypes have an intermediate position, because on one hand they are listed in a hierarchical sequence, exclusive for each soil type, but many subtypes have universal definitions, identical through the classification (that make them similar to the principal qualifiers in WRB 2015, which also are hierarchically listed within each Reference Soil Group, but have universal definitions/ criteria).

Soil type is the basic classification unit of SGP6. It is distinguished based on a specific sequence of genetic horizons, developed from a specific parent material and under specific environmental conditions. Thus, the soil type is featured not only by the presence of certain genetic or diagnostic horizons, but also the presence of associated properties or materials of 
primary importance for the soil origin and the uniqueness of its physicochemical and biological properties. For distinguishing soil types, the traditions of Polish pedology have high importance.

The highest classification category is the soil order. It is distinguished based on the presence (or absence) of diagnostic horizons that reflect the action of particular soil-forming processes that transform the original parent material under specific environmental conditions, with a smaller or larger human contribution; taking into account the time perspective, i.e. the duration of pedogenic processes from the exposure, deposition or redeposition of the parent material. Soil orders are sets of soil types (basic classification units) and are distinguished mainly for systematic ordering of soil units and higher clarity of classification, as well as for a comprehensive review of the impact of main soilforming factors and processes on the soil cover structure in Poland. Technically, the soil orders support rapid allocation of soils under classification to appropriate classification units. The limited number of nine orders makes it easy to remember the structure of classification and to understand the fundamental differences between the major classification units. First of all, however, the soil orders, as a collective and the highest classification categories, indicate the priorities of classification system, particularly useful where more than one diagnostic horizon or various diagnostic properties and materials are simultaneously present in the soil profile. The Polish Soil Classification (SGP6) distinguishes 30 soil types grouped in nine orders (fig., tables 4-5). The sequence of soil orders is retained after earlier versions of Polish Soil Classfications, i.e. starts with weakly developed soils, followed by better developed mineral soils with diagnostic horizons, then hydromorphic soils, organic soils, and antrhropogenic soils as the last order (table 6). This sequence reflects the advancement of (mineral) soil development and is regarded the formal construction of SGP6. However, the arrangement of soil orders in the key (table 4) is different, that was technically necessary to highlight the priotrities of diagnostic features and to simplify the classification process.

The soil subtype is distinguished to emphasize the diversity of morphological or physicochemical features within the soil type, having high importance for the interpretation of the soil origin and its expected future evolution, as well as to stress the specific environmental soil functions. Among the subtypes, the following categories are distinguished:

1. "typical" subtypes - represent the most characteristic for the type expression of soil features, including the sequence of genetic horizons or combinations of diagnostic horizons and properties; in the list of subtypes they are logically always placed as last;

\section{Polish Soil Classification, 6th edition (2019)}

Hierarchical units

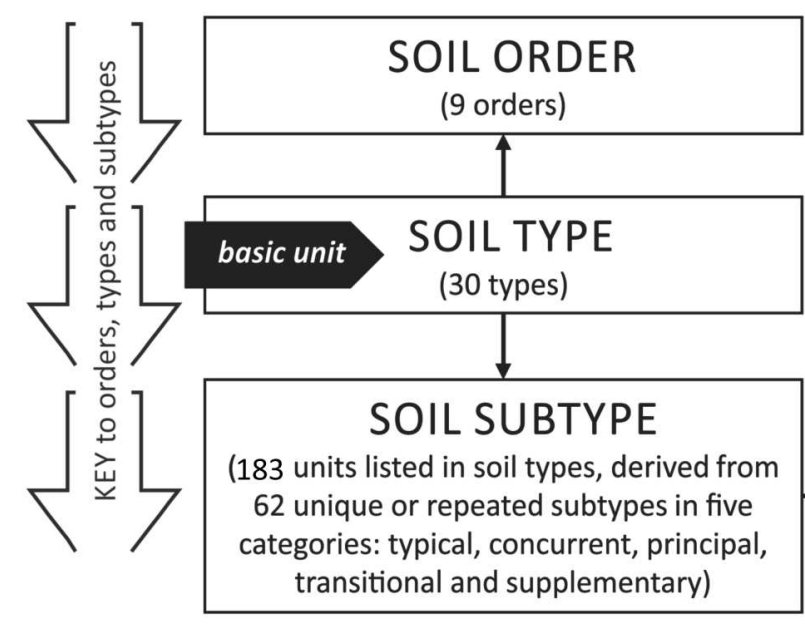

Non - hierarchical units

(optional; added if required)

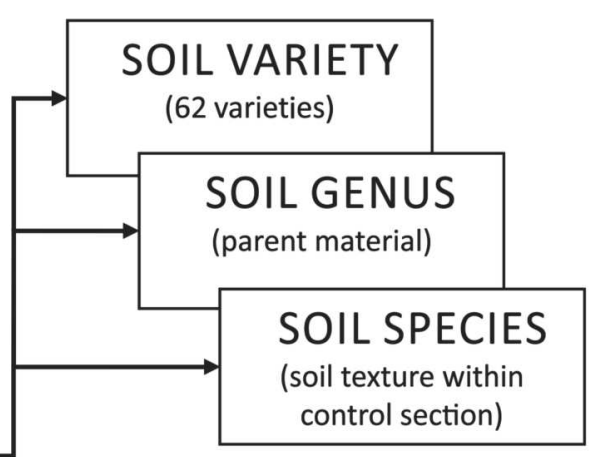

FIGURE. Architecture of the SGP6 
TABLE 4. Key to soil orders and soil types

SOIL ORDERS
Soils having organic material,
either:
1. starting $\geq 30 \mathrm{~cm}$ from the soil surface and
having within $\geq 60 \mathrm{~cm}$ from the soil surface
combined thickness of $\geq 30 \mathrm{~cm}$; or
2. starting at the soil surface and having a
thickness of $\geq 10 \mathrm{~cm}$, directly overlying
continous rock or coarse fragments the
interstices of wich are filled with organic material
to the depth of $\geq 30 \mathrm{~cm}$ from the soil surface

GLEBY ORGANICZNE

Other soils:

1. having an antrik or hortik horizon $\geq 50 \mathrm{~cm}$ thick; or

2. having technogenic hard layer or geomembrane of any thickness on the soil surface or starting within $\geq 100 \mathrm{~cm}$ of soil surface; or

3. deeply mixed or having the thick heap material, or having a combination of these two features reaching the depth $\geq 50 \mathrm{~cm}$ (if individually they do not futfill the tickness for deep mixing or thick heap material;

4. having:

(A) $\geq 20 \%$ (vol., weigh. average) of artefacts in the upper $100 \mathrm{~cm}$ soil layer (or to continuous rock/technogenic hard layer if shallower), or (B) $\geq 10 \%$ (vol., weigh. average) of reactive artefacts in the upper $100 \mathrm{~cm}$ soil layer (or to continuous rock/technogenic hard layer if shallower)

\section{GLEBY ANTROPOGENICZNE}

Other soils having both (a) a wertik horizon starting $\geq 100 \mathrm{~cm}$ from the soil surface, and (b) $\geq 30 \%$ clay in all soil layers from the soil surface to the wertik horizon

GLEBY PECZNIEJACE

Other soils having a mollik, umbrik or arenimurszik horizon ( $\geq 30 \mathrm{~cm}$ thick)

GLEBY CZARNOZIEMNE
SOIL TYPES

Organic soils having murszik horizon $\geq 30 \mathrm{~cm}$ thick

Gleby murszowe

Other organic soils which, below murszik horizon $<30 \mathrm{~cm}$ thick (if present), have peat that constitute $>50 \%$ of organic material within $\geq 100 \mathrm{~cm}$ or $>50 \%$ of all organic material if it does not reach the depth of $100 \mathrm{~cm}$

Gleby torfowe

Other organic soils having limnic material

Gleby limnowe

Other organic soils

Gleby ś ciółkowe

Soils that meet both:

(a) have an antrik or hortik horizon $\leq 50 \mathrm{~cm}$ thick, or fulfill the criteria for deep mixing caused by agricultural, horticultural or forest management and contain $<20 \%$ vol., weigh. average) of artefacts to the depth of $100 \mathrm{~cm}$ from the soil surface, and (b) do not have geomembrane or technogenic hard layer starting $\geq 100 \mathrm{~cm}$ from the soil surface

Gleby kulturoziemne

Other soils

Gleby technogeniczne

All soils that the criteria for the soil order

Wertisole

Soils having an arenimurszik horizon

Gleby murszowate

Other soils located on the Holocene alluvial terraces and having fluvic material starting $\geq 150 \mathrm{~cm}$ from the soil surface

Mady czarnoziemne

Other soils having mollik horizon, and:(a) have a continuous/weathered calcareous or gypsum rock starting $\geq 40 \mathrm{~cm}$, or

(b) directly below the humus horizon, have a layer $\geq 30 \mathrm{~cm}$ thick (or down to continuous rock, if shallower), which contains carbonates (or gypsum) in the fine earths and $\geq 10 \%$ (weigh. average) of calcareous/gypsum rock fragments in the skeleton fraction (i.e. $\geq 2 \mathrm{~mm}$ in diameter), or

(c) directly below the humus horizon have a layer $\geq 30 \mathrm{~cm}$ thick of limnic material containing $\geq 40 \% \mathrm{CaCO}_{3}$

Rędziny czarnoziemne

Other soils having the surface layer of colluvial material $\geq 50 \mathrm{~cm}$ thick, or $\geq 30 \mathrm{~cm}$ thick, if the colluvial material overlies the organic material

Gleby deluwialne czarnoziemne

Other soils having a mollik horizon and $\mathrm{pH}_{\mathrm{w}} \geq 5.5$ prevailing to a depth of $100 \mathrm{~cm}$ from the soil surface, and having one or both of the following:

(a) gleyic properties, or

(b) stagnic properties covering $>80 \%$ of the soil layer cross-section and having thickness of $\geq 25 \mathrm{~cm}$, both starting $80 \mathrm{~cm}$ from the soil surface (or directly below the humus horizon, if $>80 \mathrm{~cm}$ thick)

Czarne ziemie 
Table 4 continued

\begin{tabular}{|c|c|}
\hline SOIL ORDERS & SOIL TYPES \\
\hline & $\begin{array}{l}\text { Other soils having (a) mollik horizon, and (b) kalcik horizon or the layer containing } \\
\text { secondary (pedogenic) carbonates both starting } \geq 150 \mathrm{~cm} \text { from the soil surface } \\
\text { Czarnoziemy }\end{array}$ \\
\hline & Other soils having a mollik or umbrik horizon \\
\hline $\begin{array}{l}\text { Other soils having an argik horizon starting } \leq 100 \\
\text { from the soil surface } \\
\text { GLEBY PLOWOZIEMNE }\end{array}$ & All soils that meet the criteria for the soil order \\
\hline $\begin{array}{l}\text { Other soils having a spodik horizon starting } \\
\leq 100 \mathrm{~cm} \text { from the soil surface, or starting } \leq 75 \\
\mathrm{~cm} \text { from the soil surface if coarse-skeletic } \\
\text { material is present and starts from the soil } \\
\text { surface }\end{array}$ & All soils that meet the criteria for the soil order \\
\hline
\end{tabular}

\section{Other soils having, either: Soils with gleyic properties starting $\geq 30 \mathrm{~cm}$ from the soil surface}

1. gleyic properties starting $\leq 30 \mathrm{~cm}$ from the

Gleby gruntowo-glejowe

2. stagnic properties covering $\geq 50 \%$ of the soil layer that starts $\leq 25 \mathrm{~cm}$ from the soil surface and is directly underlain by layer with gleyic properties, or

Other soils

Gleby opadowo-glejowe

3. stagnic properties covering $\geq 50 \%$ of the soil layer (in every subhorizon) starting from $\leq 25 \mathrm{~cm}$ and having thickness $\geq 50 \mathrm{~cm}$ or $\leq 25 \mathrm{~cm}$, if directly underlain by continuous rock or impermeable (hardly permeable) soil layer

\section{GLEBY GLEJOZIEMNE}

Other soils having a kambik, siderik or rubik horizon, or soils having a B horizon that meets the criteria for kambik horizon, except of texture,

Other soils located on the Holocene alluvial terraces, polders, or plain sea/lake shores having fluvic material starting $\leq 150 \mathrm{~cm}$ from the soil surface

Mady brunatne

Other soils, which:

(a) have a continuous/weathered calcareous or gypsum rock starting $\leq 40 \mathrm{~cm}$ from the soil surface, or

(b) in the layer from $30 \mathrm{~cm}$ down to $60 \mathrm{~cm}$ (or down to continuous rock, if shallower) contains carbonates (or gypsum) in the fine earths and $\geq 10 \%$ (weigh. average) of calcareous/gypsum rock fragments in the skeleton fraction (i.e. $\geq 2 \mathrm{~mm}$ in diameter)

Rędziny brunatne

Other soils having a kambik horizon

Gleby brunatne

Other soils

Gleby rdzawe

Other soils

GLEBY SLABO UKSZTALTOWANE

\section{Soils having:}

(a) combined thickness of all organic and mineral layers to the continuous rock $\leq 10$ $\mathrm{cm}$, or

(b) combined thickness of $\mathrm{O}+\mathrm{A}+\mathrm{E}+\mathrm{B}+\mathrm{BC}$ horizons (if present) in a loose material, including coarse-skeletic material, $\leq 10 \mathrm{~cm}$

Gleby inicjalne

Other soils located on the Holocene alluvial terraces, polders, or plain sea/lake shores having fluvic material starting $\leq 50 \mathrm{~cm}$ from the soil surface 


\section{Other soil, which:}

(a) have a continuous/weathered calcareous or gypsum rock starting $\geq 30 \mathrm{~cm}$ from the soil surface, or

(b) in the layer from $30 \mathrm{~cm}$ down to $60 \mathrm{~cm}$ (or down to continuous rock, if shallower) contains carbonates (or gypsum) in the fine earths and $\geq 10 \%$ (weigh. average) of calcareous/gypsum rock fragments in the skeleton fraction (i.e. $\geq 2 \mathrm{~mm}$ in diameter), or

(c) have a layer $\geq 30 \mathrm{~cm}$ thick, starting $\geq 30 \mathrm{~cm}$ from the soil surface, of drained limnic material containing $>40 \% \mathrm{CaCO}_{3}$

Rędziny waś ciwe

Other soils having a continuous rock starting $\geq 50 \mathrm{~cm}$ from the soil surface

Rankery

Other soils having the surface layer of colluvial material $\geq 50 \mathrm{~cm}$ thick, or $\geq 30 \mathrm{~cm}$ thick if colluvial material overlies the organic material

Gleby deluwialne właś ciwe

Other soils having:

(a) a sandy texture (sand or loamy sand classes) to a depth $\geq 100 \mathrm{~cm}$ from the soil surface and the layers of finer texture $<10 \mathrm{~cm}$ thick (in total), and

(b) $<40 \%$ of skeletal fragments, excluding the buried periglacial/moraine pavement, to a depth of

$100 \mathrm{~cm}$ from the soil surface, and

(c) layer(s) containing $\geq 2 \% \mathrm{CaCO}_{3}$ has a (total) thickness $<10 \mathrm{~cm}$ to a depth of $50 \mathrm{~cm}$ or $<30$ $\mathrm{cm}$ to a depth of $100 \mathrm{~cm}$ from the soil surface

Other soils

Arenosole

2. "concurrent" subtypes - substitute the "typical" subtype in soil types, if at least two subtypes have the features equally typical for the soil type (e.g. fibric, hemic and sapric subtypes in peat soils, or ordinary, leached and acid subtypes in brown soils); they are listed at the beginning of the list of subtypes;

3. "principal" subtypes - refer to additional features of primary importance for the interpretation of soil genesis, land use or environmental functions of the soil; their names are used instead of (replace) the name of soil type, also in combinations with other subtypes; however, the priority subtype does not combine with any other priority subtype; unique names of the priority subtypes aims to preserve the traditional soil nomenclature, i.e. soil names that have become established in Polish pedology, and to simplify (shorten) the soil names; the primary subtypes are marked with the symbol * (asterisk) in the hierarchical lists;

4. "transitional" subtypes - refer to the presence of the horizons and properties that are diagnostic for other soil types, but in a given soil type are considered less important (e.g. the kambik horizon in a chernozemic soil) or are weakly developed (e.g. have Fe-illuvial horizon that does not meet the criteria for spodik), or occur too deep (e.g. strong gleyic properties at a depth of $50-70 \mathrm{~cm}$ );

5. "supplementary" subtypes - indicate a special expression of pedogenic features or the presence of specific soil properties or materials.
A new, non-hierarchical classification category is the soil variety. Its concept is derived from the Classification of Forest Soils of Poland (Klasyfikacja gleb leśnych Polski 2000) and is close to the concept of supplementary qualifiers of WRB 2015. Soil variety is optionally added to indicate (a) lithogenic or pedogenic (secondary) features accompanying the main soil-forming process, (b) particularly strong, or adversely, relatively poor expression of features potentially important for soil classification, (c) restrictions for soil use, including anthropogenic transformation, salinity and soil pollution, (d) soil trophic potential for forest habitats (Brożek et al. 2000), etc. Soil varieties have the same (universal) definitions throughout the classification that allows an identification of a given soil feature regardless of the soil order or type. Moreover, the third and subsequent subtypes, if their diagnostic features were identified in the soil under classification, may be listed as soil variety (taking into account that only two subtypes may be applied in this rank). Also, the subtype not included in the hierarchical list of subtypes within the particular soil type of SGP6 may be indicated as an additional soil variety, if its diagnostic features were identified in a soil profile under consideration (table 6).

The non-hierarchical category of soil genus determines the kind of parent material from which the soil was developed, taking into account its variability (lithological discontinuity) within the profile. And the last, non-hierarchical category of soil species deter- 
mines the soil texture (particle-size distribution) throughout the soil profile, also taking into account possible variability (that may be both of pedogenic or lithogenic origin). The names of texture classes in SGP6 are used after the Soil Texture Classification of Soil Science Society of Poland (2009).

\section{BRIEF DESCRIPTION AND CORRELATION OF MAJOR SOIL UNITS}

The correlation table (table 5) includes the closest English translations for the Polish names of soil orders, types and subtypes (SGP6), as well as their most common and typical equivalents in WRB2015 and ST2014 classifications. The correlation table was developed taking into account previous statements of Kabała et al. (2016) and Świtoniak et al. (2016).

The first order, weakly developed soils (gleby stabo uksztaltowane), brings together soils (a) at the early (initial) stage of development, where the thickness of soil profile (regolith) to the continuous rock is $\geq 10 \mathrm{~cm}$ or the combined thickness of all genetic horizons $(\mathrm{O}+\mathrm{A}+\mathrm{E}+\mathrm{B}$, if present $)$ in an unconsolidated material is $\geq 10 \mathrm{~cm}$, and (b) soils at early stage of development, thicker than initial (raw) soils, but without any diagnostic horizon except for folik. WRB2015 allocates such soils among different RSGs characterized by little or no profile differentiation. The first type of raw mineral soils (table 5) consists of six subtypes of raw siliceous rocky and raw rendzina rocky soils correlated with (Calcaric) Lithic Leptosols, raw siliceous debris and raw rendzina debris soils correlated with (Calcaric) Hyperskeletic Leptosols (Lasota et al. 2018), raw alluvial soils (Fluvisols) and raw unconsolidated soils (Protic Regosols). The other five soil types include weakly developed soils, but thicker than raw (initial) soils. Rankers, siliceous soils with continuous rock at $\geq 50 \mathrm{~cm}$ belong to Leptosols; however, they may have a sequence of clearly developed (but not diagnostic) horizons. Ordinary rendzinas are in the majority shallow and skeletal soils rich in primary (lithogenic) carbonates (Calcaric Leptosols), but may have a folik horizon (Miechówka and Drewnik 2018). Ordinary rendzinas do not have diagnostic horizons in terms of SGP6; whereas they may have mollic in line with WRB2015 requirements (if $A$ is $\geq 20 \mathrm{~cm}$ thick). In this case, the humic ordinary rendzinas are correlated with Calcaric Leptic Phaeozems (Kabała 2018, Kowalska et al. 2019). The type of ordinary alluvial soils involves young soils on Holocene terraces, developed from fluvic material, lacking diagnostic horizons (Fluvisols). Ordinary colluvial soils are featured by evidence of successive accumulation of soil material (thicker than $50 \mathrm{~cm}$, or $30 \mathrm{~cm}$ if settled directly on peat) eroded from the above-located arable hill-slopes (Colluvic Regosols or Colluvic Arenosols). Arenosols in SGP6 are weakly developed sandy soils correlated with Arenosols in WRB2015, but the soil type in SGP6 is much "narrower" than its equivalent in WRB and does not include the initially developed and colluvial arenosols. Also, the Brunic Arenosols (WRB 2015), termed rusty soils in Poland, are moved from arenosols to rusty soils due to a thick subsurface $\mathrm{Bv}$ horizon, considered a diagnostic horizon (siderik) in SGP6. And the last soil type, regosols, may be easily correlated with Regosols in WRB2015.

The $2^{\text {nd }}$ order, brown earths (gleby brunatnoziem$n e$ ), brings together soils that have kambik, rubik or siderik diagnostic horizons (comments regarding these horizons are summarized in table 1). Therefore, particular types of brown earths of SGP6 can be correlated with different RSGs of WRB2015. Brown soils (a type) typically refer to Eutric and Dystric Cambisols; brown rendzinas are correlated with Calcaric/Dolomitic Cambisols (Kowalska et al. 2017, Zagórski 2003) and brown alluvial soils are correlated with Fluvic Cambisols (Ligęza 2016). The main reason to separate the brown rendzinas and brown alluvial soils from "ordinary" brown soils is the different parent material, different landscape position and different ecosystem/habitat functions of these soils. The other two soil types, ochrous and rusty soils are primarily sandy soils (developed from glaciofluvial, eolian and older alluvial sands), thus belonging to Arenosols in WRB2015. However, they have well-developed rubik or siderik subsurface diagnostic horizons, not recognized in WRB 2015, but easily correlated with Rubic/Chromic or Brunic qualifiers, respectively (Jankowski 2013).

The $3^{\text {rd }}$ order, podzolic soils (gleby bielicoziemne), covers the soils with a spodik horizon, merged in one soil type - gleby bielicowe, closely related to Podzols of WRB2015. The soil type includes several subtypes related in the majority to redoximorphic features and various organic horizons developed at the soil surface (Chodorowski 2009, Kabała et al. 2012, Waroszewski et al. 2013). In Polish tradition, podzolic soils having and lacking topsoil A horizon are distinguished into separate units, a fact which also influences the number of subtypes and their combinations in SGP6. Moreover, only the podzols with clearly preserved eluvial horizon (albik) are considered the "typical", whereas podzolic soils laking albik are classified as latent podzolic soils ("krypto-podzols"). The placement of podzolic soils after, not before, the chernozemic soils in the key to soil orders excludes the soils with mollik/umbrik horizons from podzolic soils in SGP6. 


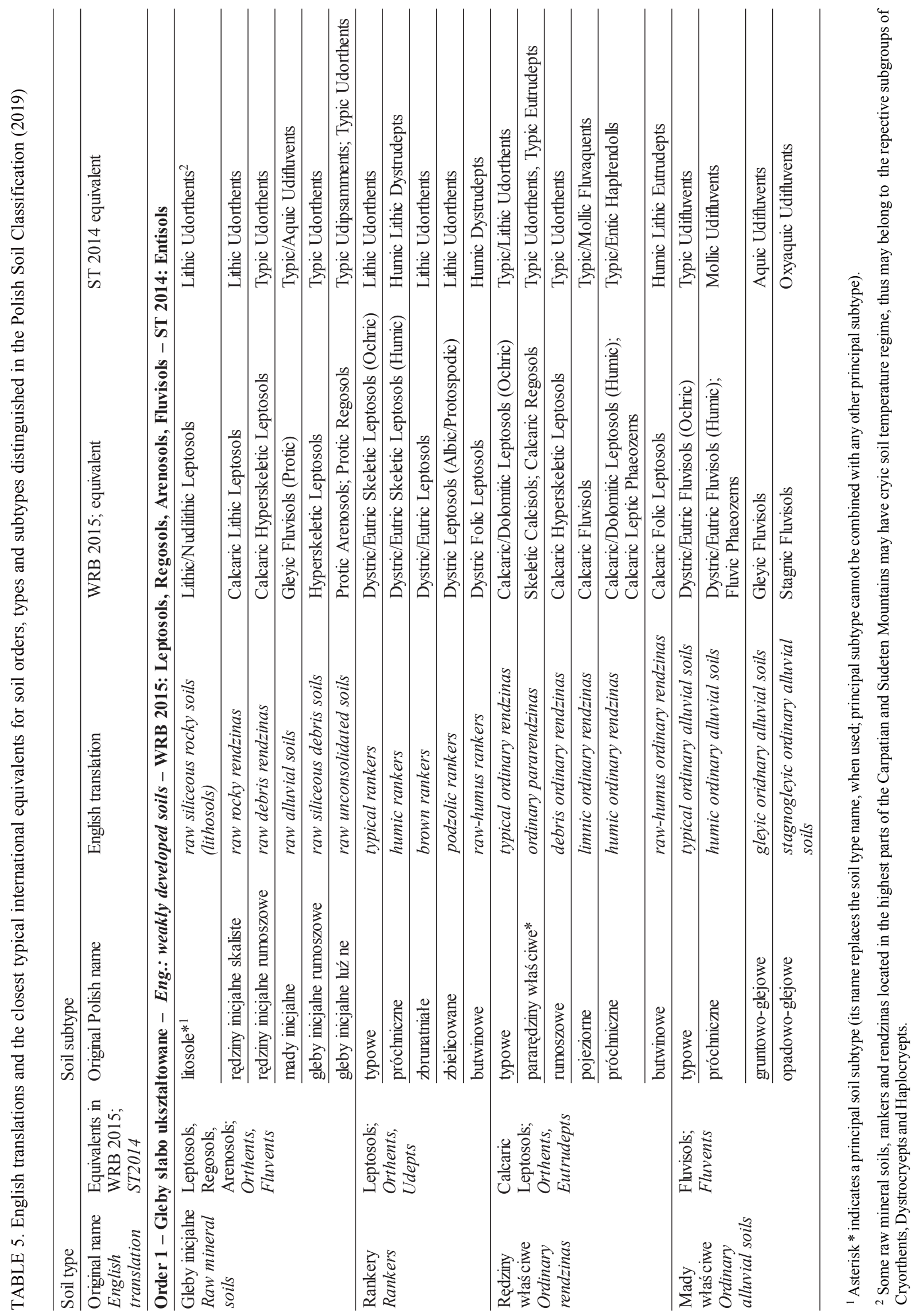




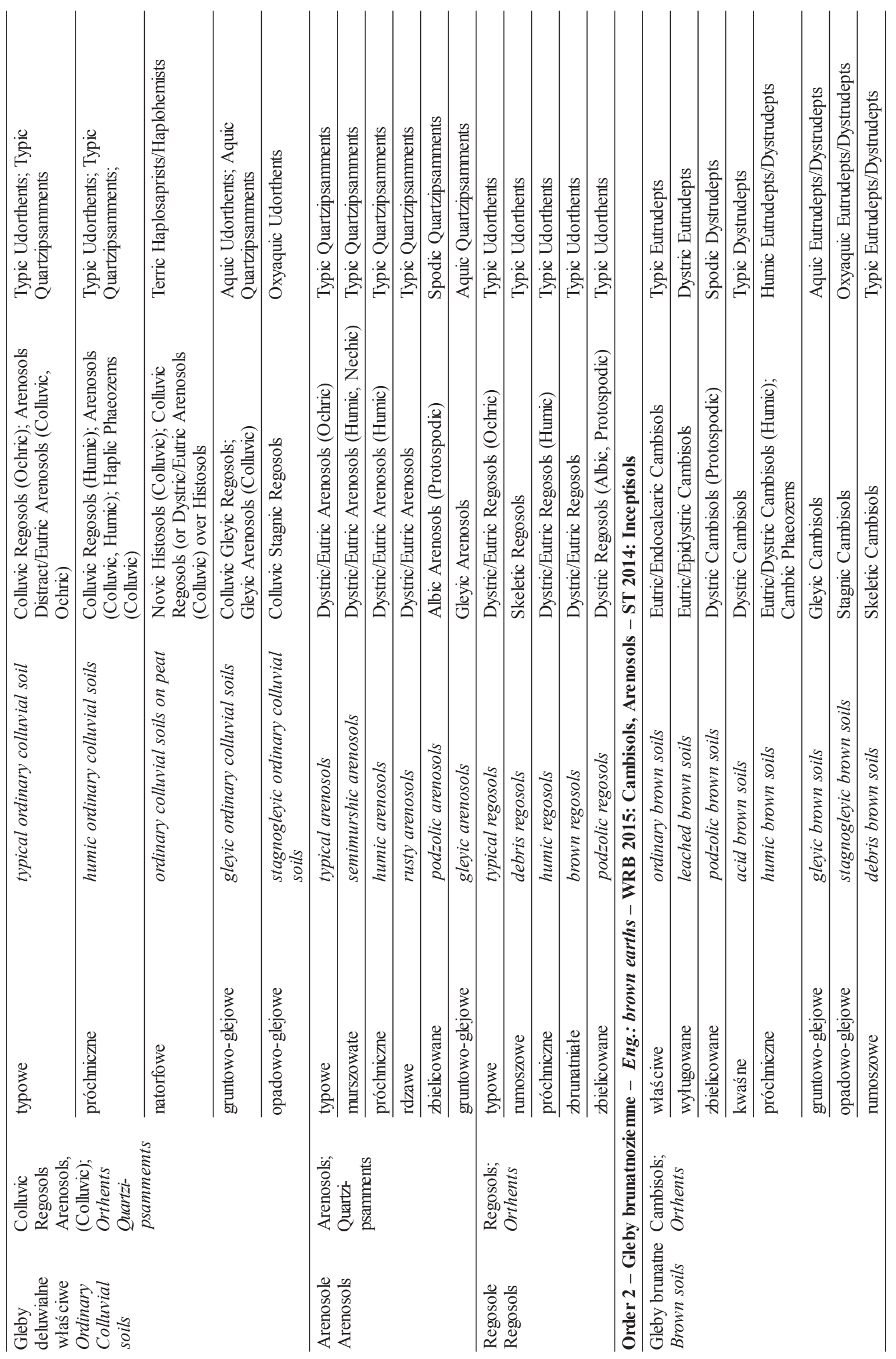




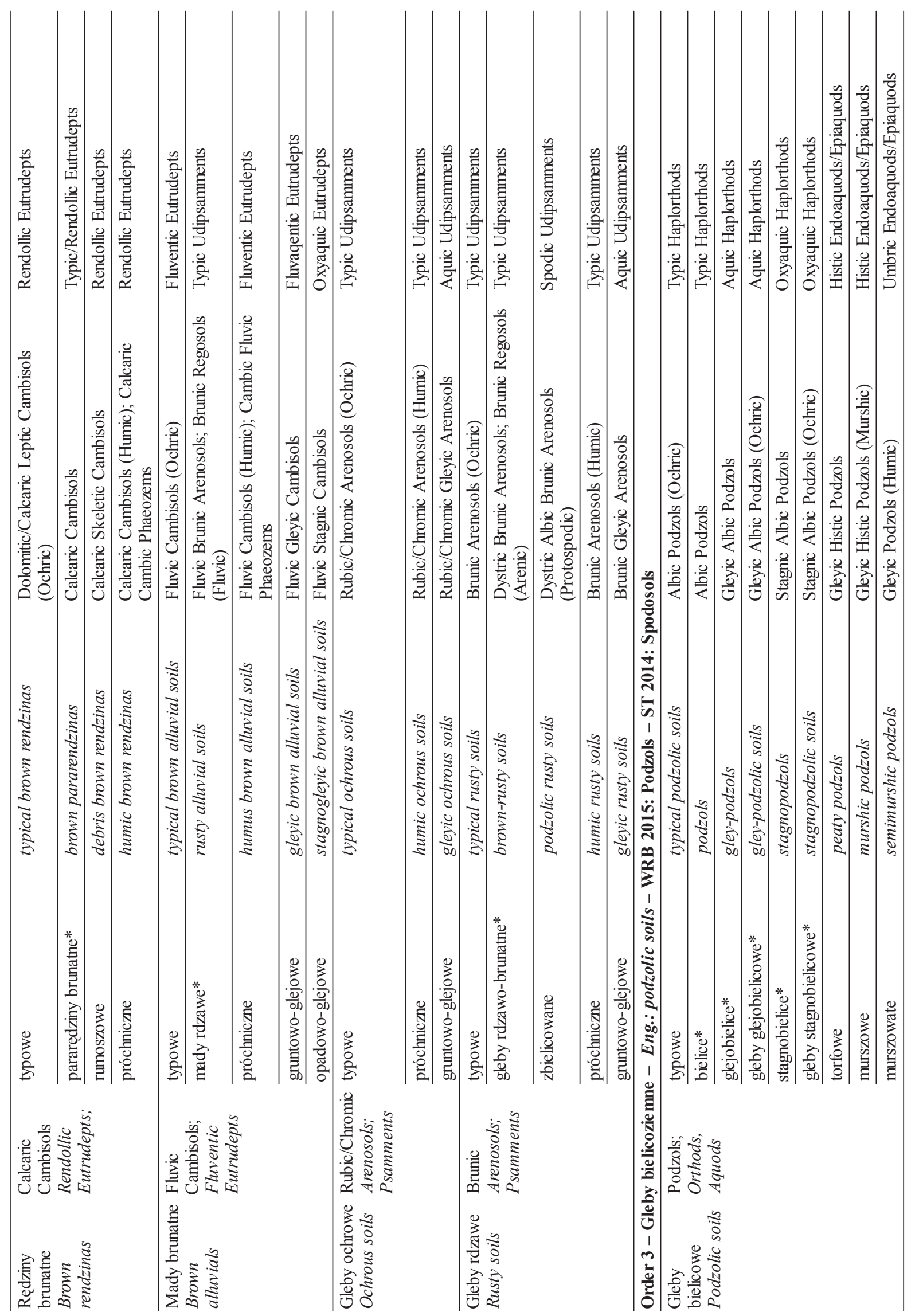



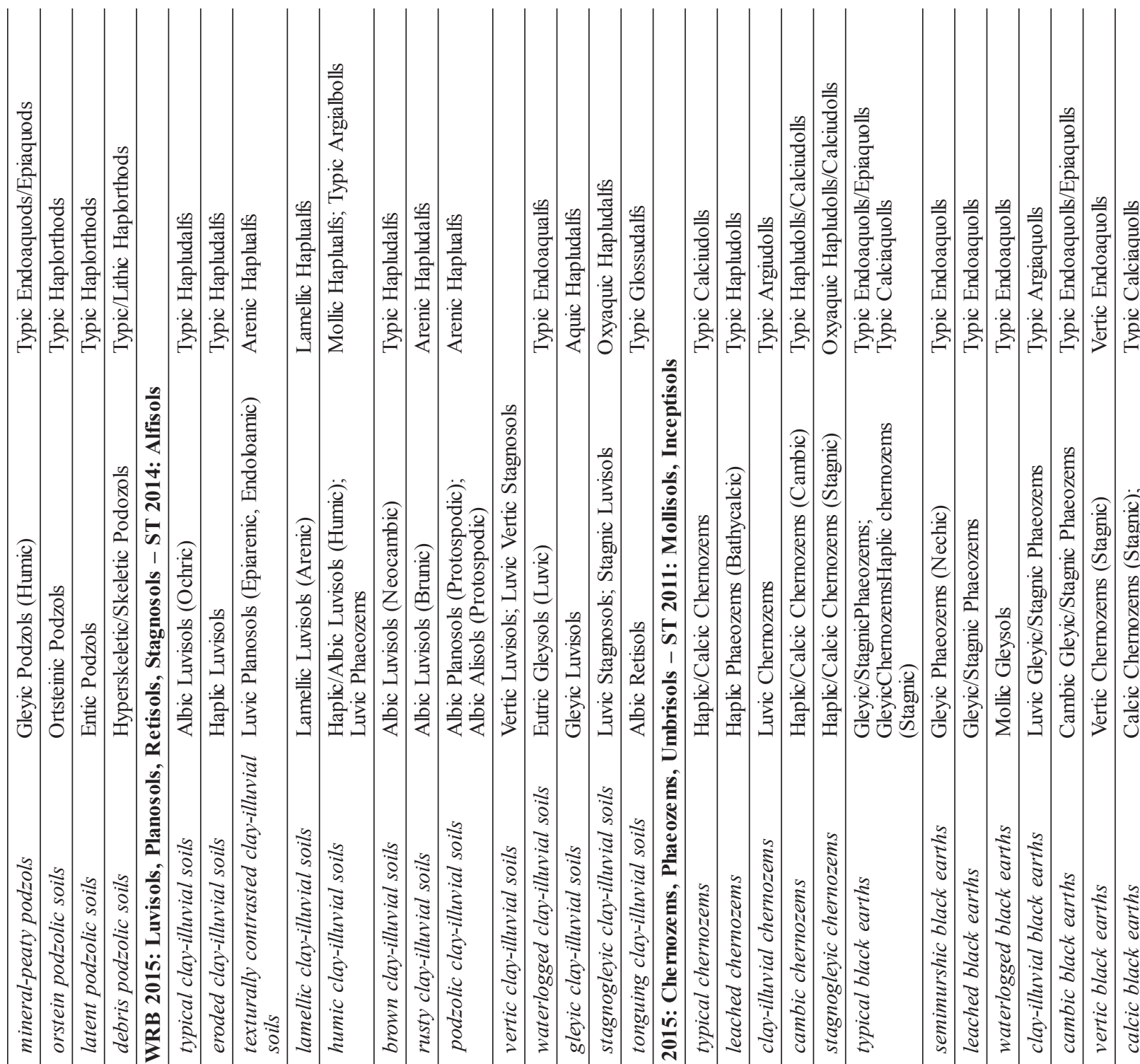

(1)

$ص$ 电

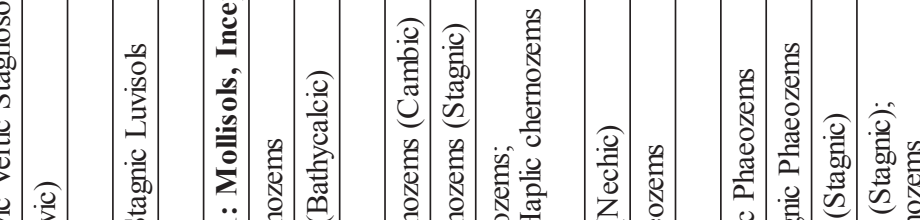

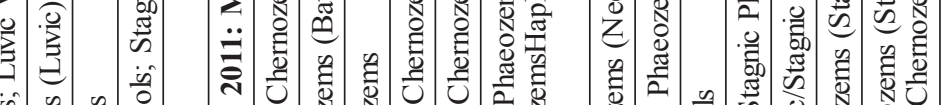

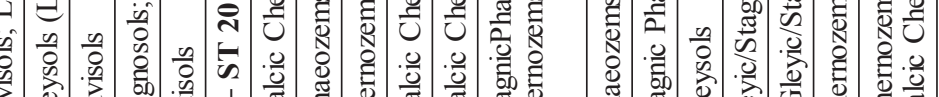

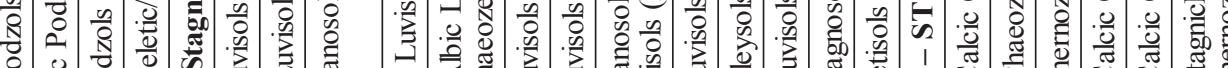

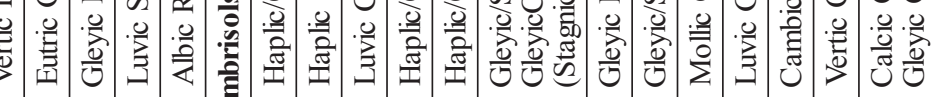

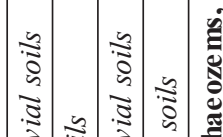
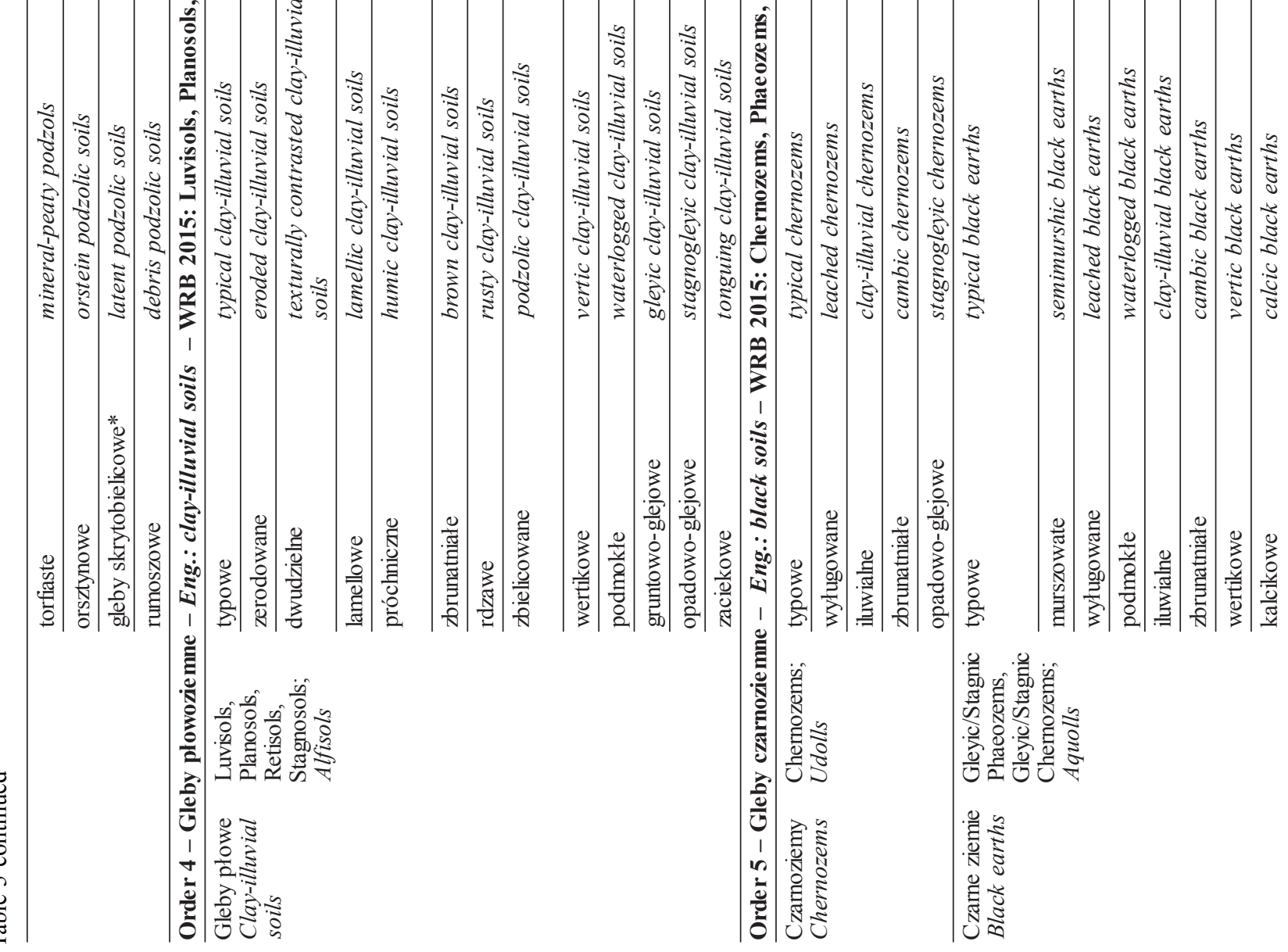

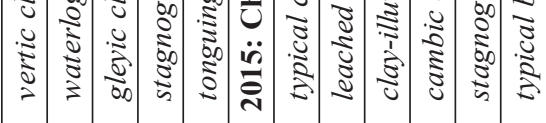

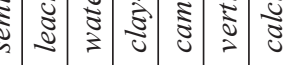
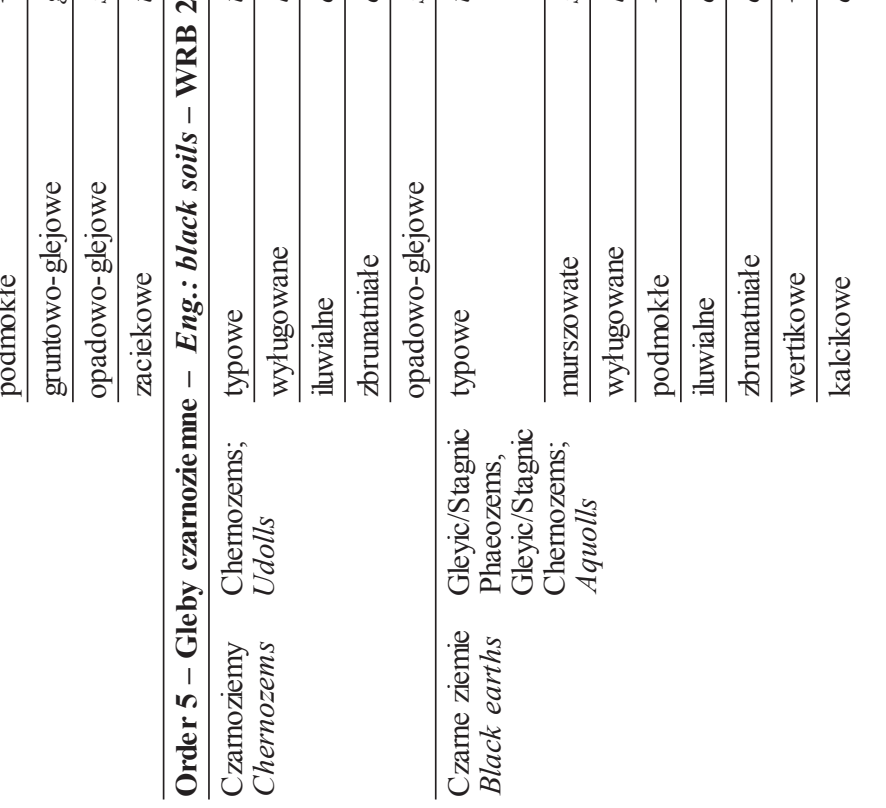


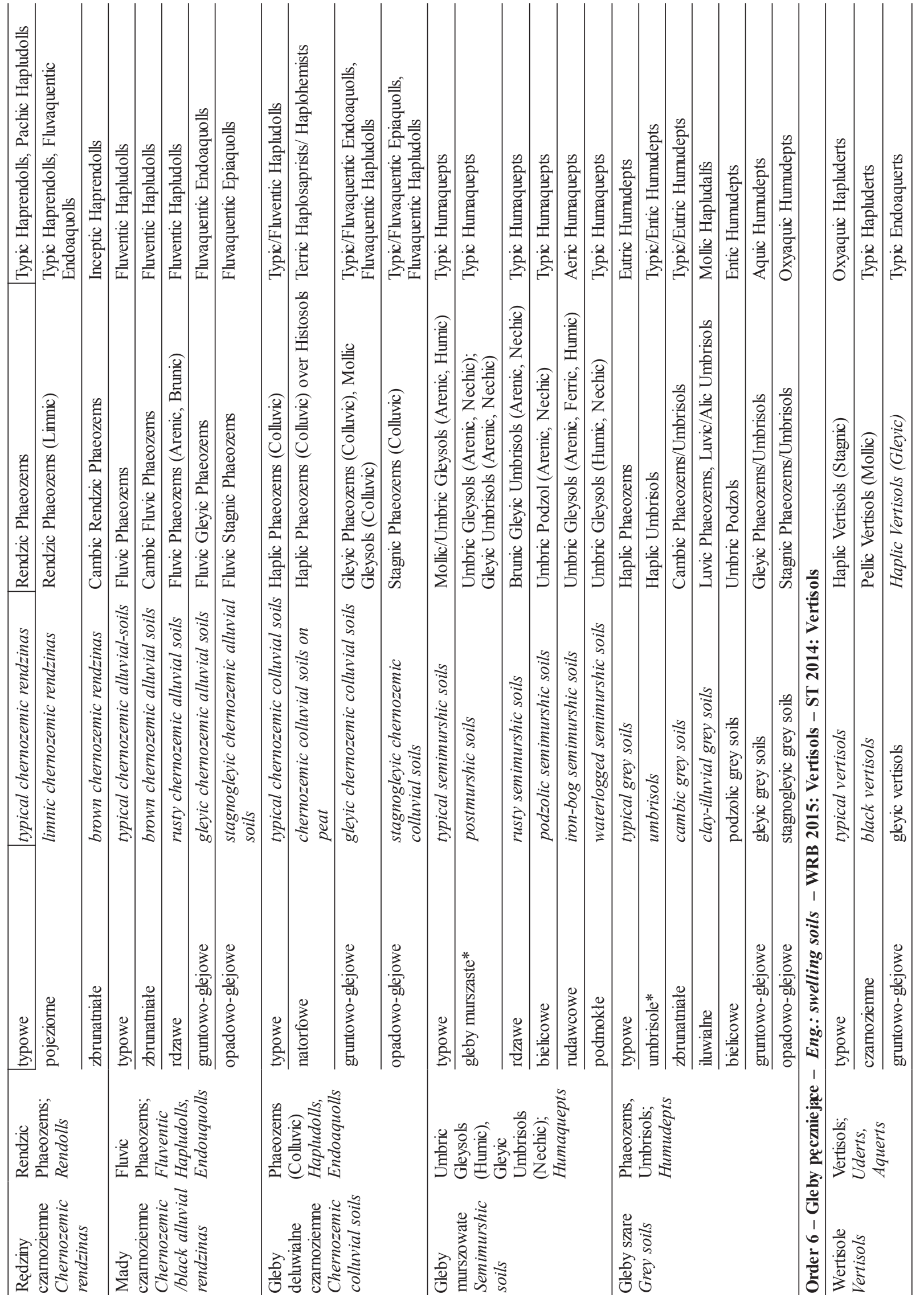




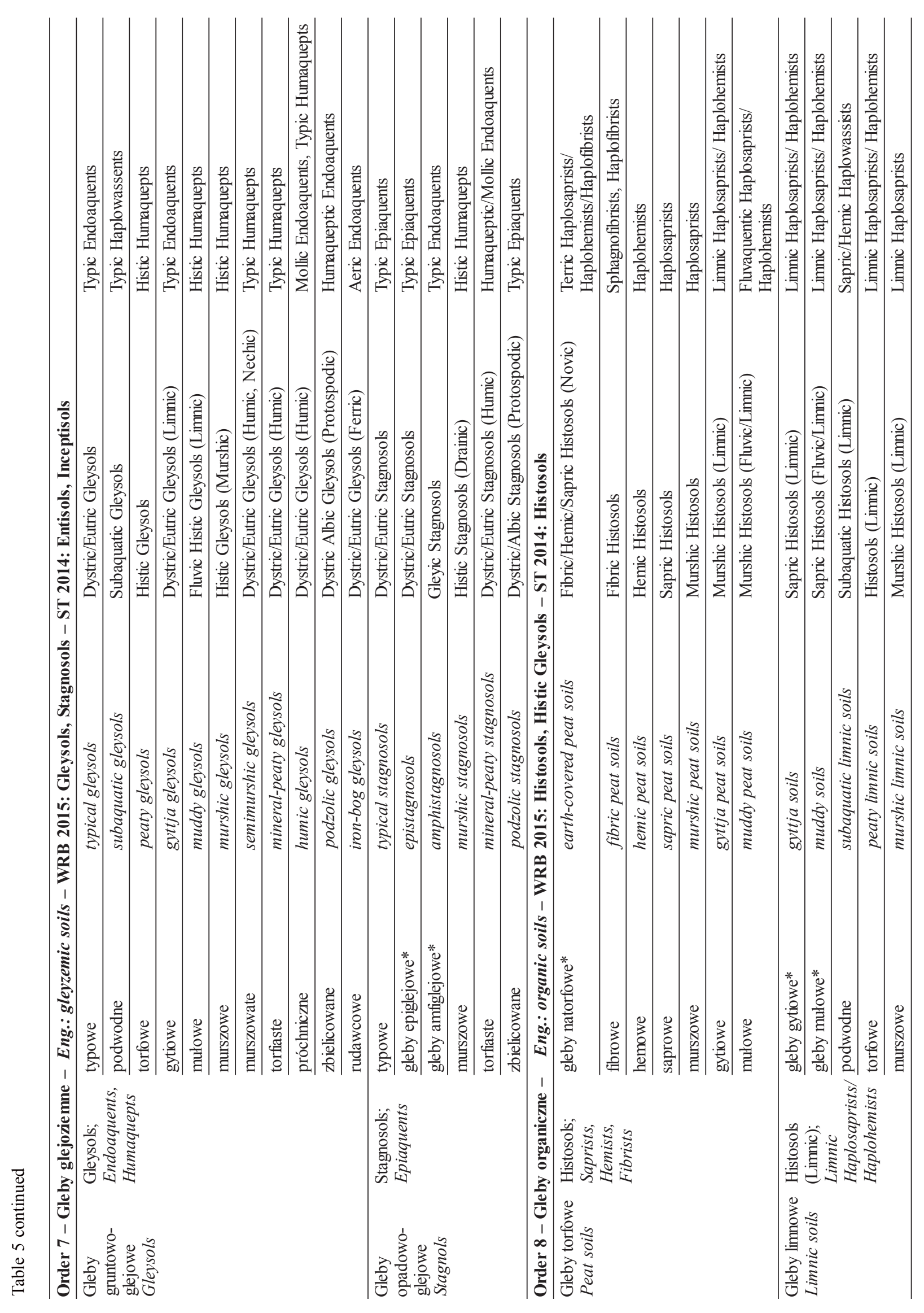




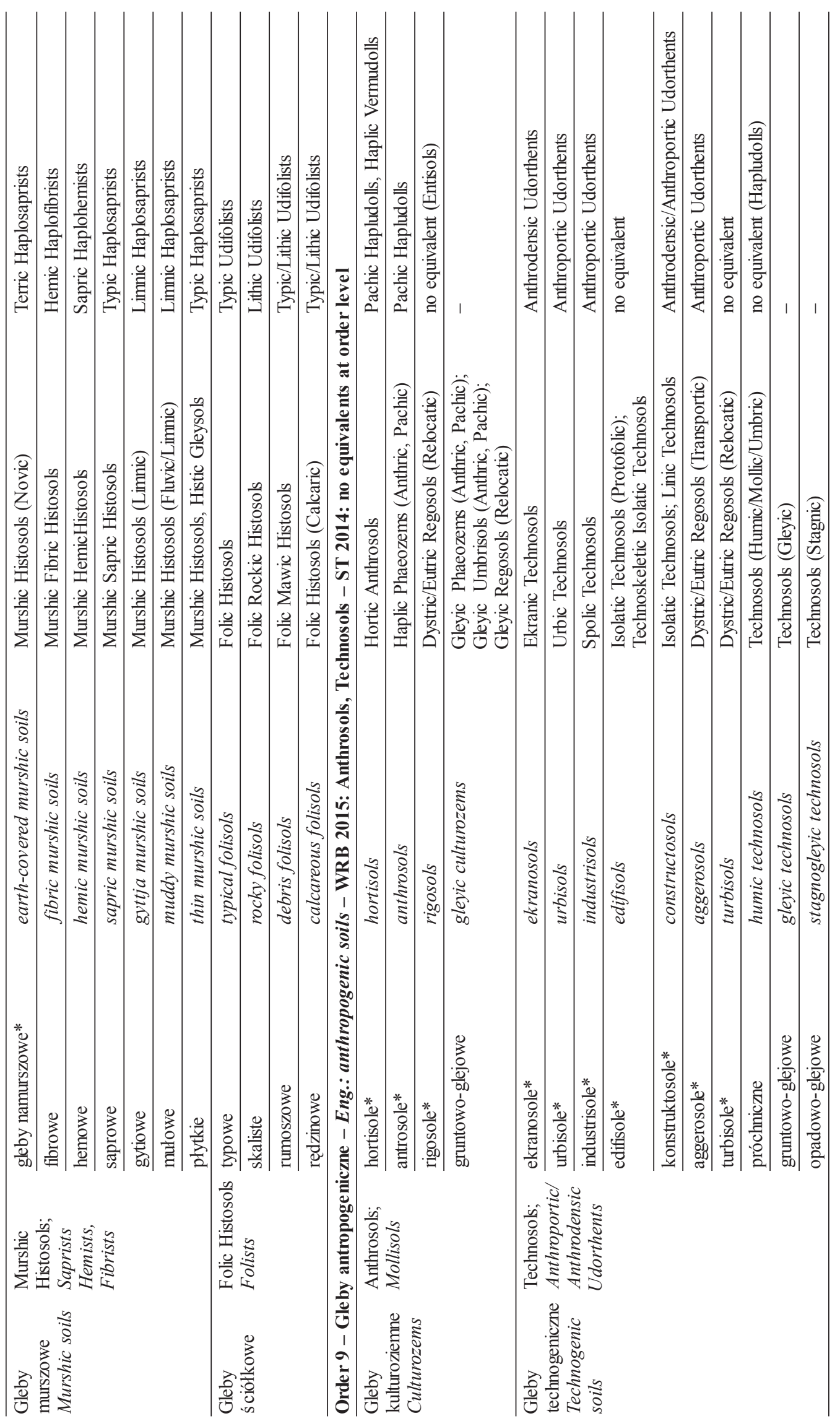


The $4^{\text {th }}$ order of clay-illuvial soils (gleby plowoziemne) consists of one soil type (gleby ptowe) that brings together various soils with an argik horizon. The placement of this order (in the key to soil orders, table 4) after the chernozemic soils excludes soils with mollik/umbrik horizons, whereas its placement before podzolic soils and gleyzemic soils gives a higher priority for the argik horizon compared to the spodik horizon and stagnic/gleyic properties. Only the soils with "complete" sequence of crucial genetic (E-Bt) and diagnostic (eluwik-argik) horizons are considered "typical", whereas soils featured by Ap-Bt morphology are distinguished as eroded (truncated) clayilluvial soils (Kobierski 2013, Switoniak 2014, Świtoniak et al. 2016). All these soils may be correlated with Luvisols in WRB2015 if the stagnic properties are weak to medium strong, or with Luvic Stagnosols if stagnic properties are strongly developed and start $\geq 25 \mathrm{~cm}$ from the soil surface (Waroszewski et al. 2018). Many of such soils, both silty- and loamy-textured, have eluvial tongues in an argik horizon, thus commonly were classified as Albeluvisols in accordance with previous WRB versions (Szymański et al. 2011). Former Albeluvisols were also correlated with texturally contrasted soils (gleby płowe dwudzielne), i.e. soils with sandy topsoil and an abrupt textural difference at $\geq 50 \mathrm{~cm}$ from the soil surface, if eluvial tongues were present in the Bt horizon. At present, the texturally contrasted soils with stagnic properties are correlated with Planosols (irrespectively of the presence of tonguing) or with Retisols, if stagnic properties are weak (or absent) and tonguing is clearly developed (Komisarek and Szałata 2008; Kozłowski and Komisarek 2017; Musztyfaga and Kabala 2015; Waroszewski et al. 2019). This complicated system of equivalents is due to splitting the soils with an argic horizon into several separate RSGs in WRB 2015. In contrast, in SGP6, all these features are indicative of separate subtypes listed hierarchi-cally (table 5), that may be used to name the soil individually or in combination, still within one type of clay-illuvial soils (gleby ptowe). Extremely leached clay-illuvial soils, featured by very low base saturation and podzolization (gleby plowe zbielicowane) have to be correlated with Alisols, and particularly wet (waterlogged) clay-illuvial soils (gleby ptowe podmokte) with gleyic properties starting near the surface, have their equivalent in Gleysols (Luvic). Most of arable clayilluvial soils in Poland have a plough layer thicker than $20 \mathrm{~cm}$ (due to the standard depth of ploughing) that may fulfil the requirements for a mollic horizon according to WRB2015 and result in soil „transfer” to Phaeozems. To avoid an inappropriate classi- fication of many ordinary arable Luvisols as chernozemic soils, SGP6 requires significantly higher thickness for the mollik (and umbrik) horizon, i.e. $30 \mathrm{~cm}$, instead of the $20 \mathrm{~cm}$ required in WRB2015. However, SGP6 allows simple correlation with WRB2015 by introducing the subtype of humic clay-illuvial soils (table 5), which have a mollic horizon in terms of WRB 2015.

The $5^{\text {th }}$ order of black soils (gleby czarnoziemne) brings together soils with mollik, umbrik and arenimurszik horizons allocated into seven soil types. The definition of chernozems (czarnoziemy) in SGP6 is broader than of the respective RSG in WRB 2015 because the mollik (but not chernic) horizon is required ( $\geq 30 \mathrm{~cm}$ thick) and secondary carbonates must occur at $\geq 150 \mathrm{~cm}$, irrespectively of the thickness of the mollik horizon (Labaz et al., 2018). Black earths (czarne ziemie) have a mollik horizon and strong redoximorphic features, either as gleyic or stagnic properties (Konecka-Betley et al. 1996, Labaz and Kabała 2014, Orzechowski et al. 2004). Some of these black earths have kalcik horizons below the mollik and therefore may be correlated with Gleyic/ Stagnic Chernozems in WRB 2015; the other black earths, free of secondary carbonates, usually meet the requirements of Gleyic/Stagnic Phaeozems; whereas, the waterlogged black earths may fulfill the criteria of Mollic Gleysols. The next three types of soils with a mollik horizon correspond to Phaeozems. Chernozemic rendzinas (rędziny czarnoziemne) developed from carbonate (or gypsum) rocks correlate well with Rendzic Phaeozems. The type also includes the specific subtype of limnic chernozemic rendzinas developed of drained calcareous gyttja or highly calcareous meadow/lacustrine marl (Lemkowska and Sowiński 2018; Uggla 1976). Chernozemic alluvial soils (mady czarnoziemne) typically correlate with Fluvic Phaeozems, and chernozemic colluvial soils (gleby deluwialne czarnoziemne) may be classified as Phaeozems with a Colluvic qualifier (Świtoniak 2015). The unique type of semimurszik soils (gleby murszowate) requires an arenimurszik horizon featured by elevated content of organic matter and weak binding of organic particles to mineral grains. The concept and definition of an arenimurszik horizon has a long tradition in Polish pedology and it allows distinguishing between several steps of organic material degradation and transformation of organic layers into mineral-organic and mineral soil horizons after drainage (Łabaz and Kabała 2016, Mocek 1978, Rząsa 1963). Typically, these sandy soils correlate with Gleyic Umbrisols or Umbric Gleysols. And finally, the grey soils (gleby szare) accommodate all other soils with mollik 
or umbrik horizons, which do not fulfil the criteria of any other above listed type of chernozemic soils. They are mostly correlated with Umbrisols, but some soils with mollik horizons, but lacking secondary carbonates and strong redoximorphic features, may correlated with Haplic Phaeozems in WRB 2015.

The $6^{\text {th }}$ order of swelling soils (gleby peczniejace) involves one type of soils with a wertik horizon and clayey texture throughout - wertisols, correlated simply with Vertisols of WRB2015. The most common and most important are black vertisols (wertisole czarnoziemne), correlated with the Pellic Vertisols (Mollic), and previously referred to as Smolnica soils (Mocek et al. 2009, Prusinkiewicz 2001).

The $7^{\text {th }}$ order of gleyzemic soils (gleby glejoziemne) consists of two soil types: (a) soils featured with gleyic properties starting $\geq 30 \mathrm{~cm}$ from the soil surface, well correlated with Gleysols (WRB 2015), and (b) soils featured with strong stagnic properties at a shallow depth, generally correlated with Stagnosols (WRB 2015). However, the definitions of gleysols and stagnosols in SGP6 are narrower than the respective RSGs definitions in WRB2015 and do not include soils with diagnostic horizons such as mollik, umbrik, argik and spodik, all of which are keyed out earlier (table 4).

The $8^{\text {th }}$ order of organic soils (gleby organiczne) brings together soil developed of organic material, which have a histik/murszik/folik horizon $\geq 30 \mathrm{~cm}$ thick. Although the required thickness of organic horizon for Histosols (table 4) and the required content of organic carbon in an organic material (table 3) differ in SGP6 and WRB2015, these units are in general well correlated. Separate types of peat soils, limnic soils, murszik soils and folisols, subdivided into numerous respective subtypes, provide a broad possibility to reflect the different organic soil origin, composition, transformation or degradation paths, and functions in natural and human-impacted ecosystems (Glina et al. 2017; Kalisz and Łachacz 2008, Łachacz et al. 2009, Mendyk et al. 2015, Okruszko 1969, Roj-Rojewski and Walasek 2013; Skiba and Komornicki 1983; Wasak and Drewnik 2012). The unique type of murszik soils (gleby murszowe) includes soils developed of various primary organic materials (peat, gyttja, mud etc.); those surface layers have pedogenically transformed to a depth of at least $30 \mathrm{~cm}$ after soil drainage and under crop cultivation or forest management (Glina et al. 2016, Marcinek and Spychalski 1998, Mocek 1978, Piaścik and Łachacz 1990; Rząsa 1963). The resulting murszik horizon meets the criteria of histic horizon (WRB2015), but consists in the majority of non-fibrous, humified organic material (sapric) and has higher bulk density and aggregate structure (Glina and Bogacz 2016; Piaścik and Gotkiewicz 2004), reflected in a Murshic qualifier (WRB2015).

The last, $9^{\text {th }}$ order - anthropogenic soils (gleby antropogeniczne) - consists of two types of (a) soils deeply mixed and fertilized to create a thick "chernozemic-like" topsoil horizon aimed to improve their agricultural productivity-culturozems, correlated with Anthrosols (WRB2015), and (b) transformed or created in the course of intentional industrial or constructional activity, often consisting of artefacts (tab. 3) - technogenic soils, in the majority correlated with Technosols (WRB2015). The first soil type, culturozems (gleby kulturoziemne), is traditionally distinguished if a thick $(>50 \mathrm{~cm})$ hortik or antrik horizon is present, or the soil is deeply mixed (rigosols) (Krupski et al. 2017). A new soil type of technogenic soils brings together three previous types of urbanozemic, industriozemic and saline soils (Systematyka gleb Polski 2011). The soil subtypes are distinguished based on the presence of specific kind of artefacts - urbisols and industriosols (Greinert 2015, Uzarowicz et al. 2017, 2018), the presence of the (near) surface soil coverage/sealing with impermeable layer of concrete, asphalt etc. - ekranosols (Charzyński et al. 2013a), or the presence of a geomembrane or technogenic hard layer within the soil profile (constructosols), including the concrete bunkers/fortification (Charzyński et al. 2013b). Soils on the ruins, degraded walls or roofs of buildings are distinguished as edifisols (Charzyński et al. 2015). All these soils are simply correlated with Technosols accompanied with respective Principal qualifiers (table 5). Additiolenally, technogenic soils in SGP6 involve the aggerosols - soil developed from earth material poor in artefacts (thick heap material), transported more or less locally that forms an antropogenic convex relief form (e.g. dam, road embankment) or fulfills concave forms. These soils may be correlated in WRB2015 with Regosols (Transportic) that seems inappropriate in case of soils existing in intentionally constructed relief forms. Also, the soils transformed/ degraded due to deep mixing (in situ) of native soil at construction or other non-agricultural activity, termed turbisols, are distinguished as a subtype of technogenic soils in SGP6, but in WRB2015 must be correlated with Regosols (Relocatic). An indication of soil contamination (toxicity), alkalinization, salinization, excessive fertilization etc. may be added as a variety (table 6). 


\section{RULES FOR SOIL CLASSIFICATION}

The only appropriate way for soil classification (naming) in SGP6 is to follow the key to soil orders and types (table 4) because the key reflects the priorities of classification (i.e. the diagnostic features that have higher priority than others are listed earlier (higher) and have to be considered first). When classifying soils, the following rules must be applied:

1. Classification must always start from the beginning of the key.
2. Classification must stop in a first (the earliest) classification unit if all those requirements are met by the soil under assessment. In other words, classification may follow to the next unit in the key only if the soil does not meet all criteria listed in the unit placed earlier in the key.

3. The soil classification begins at the order level (i.e. the soil must be first allocated to an appropriate soil order).

4. The key to soil types in a selected order can be followed, when the soil certainly meets the criteria of this order and does not meet all the criteria of the previous order (placed earlier in the key).

TABLE 6. Soil varieties in Polish Soil Classification (SGP6): original names, English translations and their WRB closest equivalents

\begin{tabular}{|c|c|c|}
\hline $\begin{array}{l}\text { SGP6 } \\
\text { (names in a plural form) }\end{array}$ & English translation & Qualifiers in WRB2015 \\
\hline ( $3^{\text {rd }}$ subtype used as a variety) & \multicolumn{2}{|c|}{$\begin{array}{l}\text { If } 2 \text { subtypes (allowed maximum) have already been used in a soil name, the } 3^{\text {rd }} \text { (and eventually next } \\
\text { subtypes from the hierarchical list of subtypes) may be added as variety (varieties). }\end{array}$} \\
\hline (omitted subtype used as a variety) & \multicolumn{2}{|c|}{$\begin{array}{l}\text { If the soil under classification meets the criteria for a subtype defined in SGP6, but not indicated in } \\
\text { a hierarchical list of subtypes for given soil type, may be added to soil name as a variety. }\end{array}$} \\
\hline \multicolumn{3}{|l|}{ Barriers for roots and water } \\
\hline fragipanowe (fr) & fragipan & Fragic \\
\hline placikowe (pc) & placic & Placic \\
\hline rudawcowe $(\mathrm{ru})$ & bog iron & Ferric \\
\hline orsztynowe (or) & ortstein & Ortsteinic \\
\hline zagęszczone (zg) & densified & like Densic, but limited to the layer underlying the plough horizon \\
\hline słabolamellowe (sl) & proto-lamellar & $\begin{array}{l}\text { like Lamellic, but total thickness of lamellae not specified (may be }<5 \mathrm{~cm} \text { ); } \\
\text { Proto-lamellic }\end{array}$ \\
\hline \multicolumn{3}{|l|}{ Litho- and pedogenic features } \\
\hline limnowęglanowe (lw) & $\begin{array}{l}\text { limni- } \\
\text { calcareous }\end{array}$ & $\begin{array}{l}\text { no equivalent; to the depth of } 100 \mathrm{~cm} \text { has Limnic material that contains } \geq 20 \% \\
\mathrm{CaCO}_{3} \text { in a layer } \geq 20 \mathrm{~cm} \text { thick }\end{array}$ \\
\hline weglanowe (ca) & calcareous & $\begin{array}{l}\text { no equivalent; has a layer } \geq 10 \mathrm{~cm} \text { thick to the depth of } 50 \mathrm{~cm} \text { or } \geq 20 \mathrm{~cm} \text { to the } \\
\text { depth of } 100 \mathrm{~cm} \text {, which contains } \geq 2 \% \mathrm{CaCO}_{3} \text { in fine earths }\end{array}$ \\
\hline głęboko węglanowe (gw) & deep calcareous & Bathycalcaric \\
\hline gipsowe (gi) & gypseous & $\begin{array}{l}\text { no equivalent, but often may be correlated with Gypsiric; has a gypsiric hard rock } \\
\text { at the depth of } \leq 150 \mathrm{~cm} \text { and }>50 \% \text { of gypsiric rock fragments in the skeleton } \\
\text { fraction }\end{array}$ \\
\hline mieszane $(\mathrm{mx})$ & mixed & $\begin{array}{l}\text { no equivalent; applied to rendzina soils with a gypsiric/calcareous rock at the } \\
\text { depth of } \geq 150 \mathrm{~cm} \text {, that have (1) siliceous rock fragments in the skeleton } \\
\text { fraction, or (2) siliceous materials (e.g. quartz sand) dominating in the fine earths }\end{array}$ \\
\hline przykryte (pz) & covered & Aeolic, Epicolluvic, Novic \\
\hline czerwone $(\mathrm{cz})$ & red & Chromic, Rhodic (colour hue, moist, redder than 7.5YR) \\
\hline głęboko próchniczne (gh) & deep humic & Pachic \\
\hline zasolone (zs) & saline & Protosalic \\
\hline słono-sodowe (ss) & saline-sodic & Protosalic and Sodic \\
\hline sodowo-alkaliczne $(\mathrm{sd})$ & sodic-alkaline & Sodic, Alkalic \\
\hline kwaśno-siarczanowe (ks) & sulfate acidic & Thionic \\
\hline siarczkowe (sr) & sulfidic & Hypersulfidic \\
\hline ornitogeniczne (or) & ornithogenic & $\begin{array}{l}\text { like Ornithic; but includes also soils of bird nesting sites having microrelief } \\
\text { changed due to nest constructions }\end{array}$ \\
\hline pogrzebane (bxx) & buried & $\begin{array}{l}\text { like Thapto-, but applied to native soil (instead of simple diagnostic horizon) } \\
\text { buried under modern colluvial or anthropogenic soil }\end{array}$ \\
\hline
\end{tabular}


Table 6 continued

\begin{tabular}{|c|c|c|}
\hline \multicolumn{3}{|c|}{ Deep/weak redoximorphic features } \\
\hline $\begin{array}{l}\text { średnio głęboko gruntowo- } \\
\text { glejowe (sgg) }\end{array}$ & medium deep gleyic & like Endogleyic, but gleyic properties between 80 and $130 \mathrm{~cm}$ \\
\hline $\begin{array}{l}\text { średnio głęboko opadowo- } \\
\text { glejowe (sog) }\end{array}$ & $\begin{array}{l}\text { medium deep } \\
\text { stagnic }\end{array}$ & like Endostagnic, but stagnic properties between 80 and $130 \mathrm{~cm}$ \\
\hline $\begin{array}{l}\text { głęboko gruntowo-glejowe } \\
\text { (ggg) }\end{array}$ & deep gleyic & like Bathygleyic, but gleyic properties below $130 \mathrm{~cm}$ \\
\hline $\begin{array}{l}\text { głęboko opadowo-glejowe } \\
\text { (gog) }\end{array}$ & deep stagnic & like Bathystagnic, but stagnic properties below $130 \mathrm{~cm}$ \\
\hline słabo gruntowo-glejowe (sgg) & weakly gleyic & no equivalent, like Proto-gleyic \\
\hline słabo opadowo-glejowe (sog) & weakly stagnic & no equivalent, like Proto-stagnic \\
\hline \multicolumn{3}{|l|}{ Anthropogenic features } \\
\hline odwodnione (ow) & drained & Drainic \\
\hline zawodnione (zw) & $\begin{array}{l}\text { artificially } \\
\text { waterlogged }\end{array}$ & $\begin{array}{l}\text { no equivalent; waterlogged due to recent human activity, but stagnic or gleyic } \\
\text { properties not developed }\end{array}$ \\
\hline zaburzone $(\mathrm{zb})$ & disturbed & like Relocatic, but to the depth of $<50 \mathrm{~cm}$ \\
\hline nasypowe (ns) & heaped & like Transportic, but $<50 \mathrm{~cm}$ thick \\
\hline zrekultywowane (zr) & reclaimed & $\begin{array}{l}\text { no equivalent; technogenic soils or soils with Relocatic ot Transportic characteri- } \\
\text { stics after technical or biological reclamation, have humus horizon } \geq 10 \mathrm{~cm} \text { thick }\end{array}$ \\
\hline skażone (toksyczne) (tx) & contaminated (toxic) & Toxic \\
\hline kulturoziemne (kz) & culturozemic & Hortic, Anthric \\
\hline pomielerzowe (ml) & charcoal-pile & $\begin{array}{l}\text { no equivalent, but may meet criteria for Pretic; has a layer } \geq 20 \mathrm{~cm} \text { thick that } \\
\text { contains }>5 \% \text { (vol.) of charcoal; mostly in sites of former charcoal production }\end{array}$ \\
\hline antropo-węglowe (aw) & anthropo-carbonic & Carbonic \\
\hline antropo-siarczkowe (as) & anthropo-sulfidic & like Sulfidic, but limited to anthropogenic materials \\
\hline antropo-siarczanowe (az) & anthropo-sulfatic & no equivalent; contain sulfates of anthropogenic origin that fulfil criteria for artefacts \\
\hline \multicolumn{3}{|c|}{ Specific anthropogenic features in forest soils } \\
\hline porolne (lp) & post-arable & $\begin{array}{l}\text { no equivalent; forest soil cultivated before afforestation; have plough layer } \geq 20 \mathrm{~cm} \\
\text { thick or } \geq 10 \mathrm{~cm} \text { thick and clearly detectable differences in vegetation }\end{array}$ \\
\hline agrotroficzne (la) & agrotrophic & $\begin{array}{l}\text { no equivalent; like post-arable variety, but significantly enriched with nutrients that } \\
\text { still has clear impact on vegetation }\end{array}$ \\
\hline sylwiuprawne (ls) & sylvicultural & $\begin{array}{l}\text { no equivalent; forest soil that have plough/mixed layer } \geq 20 \mathrm{~cm} \text { thick due to forest } \\
\text { cultivation }\end{array}$ \\
\hline sylwitroficzne (ly) & sylvitrophic & $\begin{array}{l}\text { no equivalent; like sylvicultural variety, but significantly enriched with nutrients that } \\
\text { has clear impact on vegetation }\end{array}$ \\
\hline zalkalizowane (lz) & artificially alkalized & $\begin{array}{l}\text { no equivalent; forest soils that have topsoil layer alkalized due to imission of } \\
\text { alkaline industrial dust }\end{array}$ \\
\hline \multicolumn{3}{|c|}{ Trophic status of forest habitat (may be applied to non-forest soils planned for afforestation or for site comparison) ${ }^{3}$} \\
\hline dystroficzne (dy) & dystrophic & no equivalent, but correlates with Dystric \\
\hline oligotroficzne (ol) & oligotrophic & no equivalent, but correlates with Dystric \\
\hline mesotroficzne (me) & mesotrophic & no equivalent, but correlates with Eutric \\
\hline eutroficzne (eu) & eutrophic & no equivalent, but correlates with Eutric \\
\hline \multicolumn{3}{|c|}{ Water supply type in organic and mineral-organic soils } \\
\hline ombrogeniczne (om) & ombrogeneous & Ombric \\
\hline soligeniczne (zr) & soligeneous & Rheic, but limited to spring water \\
\hline fluwiogeniczne (fw) & fluviogeneous & Rheic, but limited to river (flood) water \\
\hline basenowe (ba) & $\begin{array}{l}\text { ground water } \\
\text { supplied }\end{array}$ & Rheic, but limited to ground water \\
\hline stokowe (so) & $\begin{array}{l}\text { slope water } \\
\text { supplied }\end{array}$ & like Rheic, but limited to surface and ground water on hill-slopes \\
\hline
\end{tabular}

${ }^{3}$ according to trophic soil index (SIG) (Brożek et al. 2011). 
Table 6 continued

\begin{tabular}{|c|c|c|}
\hline \multicolumn{3}{|l|}{ Peatland types and thickness } \\
\hline płytkie (pt) & shallow & Histic \\
\hline wysokotorfowiskowe (tw) & raised bog & no equivalent; dystrophic raised bog with mosses in majority \\
\hline przejś ciowo-torfowiskowe (tp) & transitional bog & no equivalent; mesotrophic transitional bog with various vegetation \\
\hline $\begin{array}{l}\text { niskotorfowiskowe } \\
\text { mechowiskowe (tnm) }\end{array}$ & moss fen & no equivalent; eutrophic fen with mosses in majority \\
\hline $\begin{array}{l}\text { niskotorfowiskowe } \\
\text { turzycowiskowe (tnt) }\end{array}$ & sedge fen & no equivalent; eutrophic fen with sedge species in majority \\
\hline $\begin{array}{l}\text { niskotorfowiskowe szuwarowe } \\
\text { (tns) }\end{array}$ & reed bed fen & no equivalent; eutrophic fen with reed bed vegetation in majority \\
\hline $\begin{array}{l}\text { niskotorfowiskowe olesowe } \\
\text { (tno) }\end{array}$ & woodland fen & no equivalent; eutrophic fen with dominant forest vegetation (mostly alder) \\
\hline
\end{tabular}

5. There is no exclusive key to soil subtypes, but the list of subtypes within a certain type is hierarchical (strictly ordered), i.e. the subtype placed earlier in the list has a higher priority than the subtypes mentioned below. Thus, the selection of subtypes should always start from the beginning of their list.

6. Soil subtypes can be combined if the soil has diagnostic features of more than one subtype. When combining subtypes, the following rules apply:

a) the "typical" subtype is excluded from the combinations (may be used as single only); it means that the "typical" subtype is used if none of the earlier listed subtypes can be applied;

b) two subtypes may be combined at maximum; the third and more subtypes, if necessary, can be added to soil name as the variety;

(c) combined subtypes cannot exclude each other in any of the listed criteria;

d) any concurrent subtype and primary subtype cannot be combined with other concurrent subtype or primary subtype;

e) the order of subtypes in the combination must follow their order in the hierarchical list of subtypes; thus, the concurrent/primary subtype will be always placed before the transitional or supplementary subtype;

(f) rules c-e apply differently in peat soils because the layers of different organic materials may occur in the soil profile in various combinations (the rules are separately specified).

7. Soil varieties are used optionally only, but for various reasons, it is recommended to record them in all fieldwork. The following rules apply at recording of soil varieties:

(a) the varieties are given in brackets after the type and subtype(s), but before the genus and species;

(b) the varieties are separated by a comma(s);

(c) the varieties in the soil name are listed in the same order as varieties are listed in the classification.

\section{CLASSIFICATION OF BURIED SOILS}

Although the Polish Soil Classification (SGP6), similarly to other contemporary international and national systems, refers mainly to soils that are currently forming and existing on the land surface, it may be also used for naming of the buried (fossil) soils - due to the absence of alternatives. However, it should be stressed that its use for classification of the buried (subsurface) soils cannot distort the sense of surface (modern) soil classification because the classification priorities are established taking into account current productivity and environmental functions of soils identified on the land surface. It is assumed that the buried soils will be distinguished rather exceptionally, mainly for scientific requirements.

SGP6 can separately classify the surface (modern) soil and the buried soil using the following rules:

1. Buried soil is a soil covered by younger sediments. The presence of the secondary soil-forming process that overlaps the original soil profile without physical coverage with the younger sediment is not a basis for distinguishing buried soil.

2. Buried soil and the overlying younger material are classified as one (surface/modern) soil, when as a whole they meet the criteria of:

(a) organic, gleyzemic or anthropogenic soil orders,

(b) the subtype of texturally contrasted clay-illuvial soils,

(c) alluvial or colluvial soil types (in the orders where they are distinguished).

3. Surface soil (developed from the younger covering material) may be classified separately from the buried soil if:

(a) the covering material is $>50 \mathrm{~cm}$ thick, and

(b) the surface soil meets all diagnostic criteria for a given soil type, and 
(c) separate classification of surface soil does not interfere with the classification of soil as a whole.

4. If the thickness of the younger covering material is $<50 \mathrm{~cm}$, the buried soil is classified with priority (like surface soil) and the presence of thin covering material is indicated as a variety.

5. In the case of anthropogenic and colluvial soils, it is possible to indicate the name of native soil (de facto buried) as the variety; however, this supplementary information does not change the classification of the modern soil recognized as an anthropogenic or colluvial one.

\section{CLOSING WORDS}

Classification, as a system comprehensively covering all pedological knowledge on soil genesis and relationships, should be periodically revised in accordance with the state-of-the-art. We hope the modernized sixth edition of Polish Soil Classification will allow for enhanced, both precise and syntetic description of soil resources in Poland, their diversity and environmental and utility functions, and will become a platform for new cartographic studies, preparation of modern soil databases and initiation of new interdisciplinary scientific studies at the highest international level. SGP6, benefiting from the achievements of global soil science, offers at the same time a number of essential modifications and innovative solutions for international classification systems.

\section{ACKNOWLEDGEMENTS}

We would like to thank all members of the Commission for Soil Genesis, Classification and Cartography of the Soil Science Society of Poland and all other people who actively supported preparartion of SGP6 with kind suggestions, professional discussion and field testing, in particular: Prof. Renata Bednarek, Prof. Stanisław Białousz, Prof. Adam Bogacz, Prof. Józef Chojnicki, Prof. Danuta Czępińska-Kamińska, Dr Wojciech Kwasowski, Prof. Andrzej Mocek, Prof. Stefan Skiba, Prof. Piotr Skłodowski and Dr hab. Wojciech Szymański.

We would like also to express our gratitude to authors of the previous editions of the Polish Soil Classification and Classfication of Forest Soils of Poland; such work has continually greatly supported development of new ideas in soil science and modern understanding of soil classification in Poland to a significant degree.

We are also grateful to the President of the Soil Science Society of Poland, Prof. Zbigniew Zagórski, for his strong support of this project.

\section{REFERENCES}

Arnold R.W., 2002. Soil classification principles. [In:] Soil Classification 2001 (Micheli E., Nachtergaele F.O., Jones R.J.A., Montanarella L., Editors). ESBR Report No 7, EUR 20398 EN, Luxembourg: 3-8.

Bednarek R., 1991. Wiek, geneza i stanowisko systematyczne gleb rdzawych w świetle badań paleopedologicznych w okolicach Osia (Bory Tucholskie). Wyd. UMK, Toruń: 422 ss.

Brevik E.C., Calzolari C., Miller B.A., Pereira P., Kabala C., Baumgarten A., Jordán A., 2016. Soil mapping, classification, and pedologic modeling: History and future directions. Geoderma 264: 256-274.

Brożek S., Lasota J., Zwydak M., Wanic T., Gruba P., Błońska E., 2011. Zastosowanie siedliskowego indeksu glebowego (SIG) w diagnozie typów siedlisk leśnych. Roczniki Gleboznawcze - Soil Science Annual 62(4): 133-149.

Charzyński P., Bednarek R., Greinert A., Hulisz P., Uzarowicz Ł., 2013a. Classification of technogenic soils according to WRB system in the light of Polish experiences. Soil Science Annual 64(4): 145-150.

Charzyński P., Hulisz P., Bednarek R., 2013b. Technogenic soils of Poland. PTSH, Toruń: 357 pp.

Charzyński P., Hulisz P., Bednarek R., Piernik A., Winkler M., Chmurzyński M., 2015. Edifisols - a new soil unit of technogenic soils. Journal of Soils and Sediments 15(8): 16751686.

Chodorowski J., 2009. Geneza, wiek oraz cechy diagnostyczne orsztynu w świetle badań gleb piaszczystych Kotliny Sandomierskiej. Wydawnictwo UMCS. Lublin: 132 pp.

Czerwiński Z., Kaczorek D., 1996. Właściwości i typologia gleb wytworzonych z rudy darniowej. Roczniki Gleboznawcze Soil Science Annual 47(1): 97-101.

Drewnik M., 2008. Geomorfologiczne uwarunkowania rozwoju pokrywy glebowej w obszarach górskich na przykładzie Tatr. Wydawnictwo UJ, Kraków: 118 pp.

Glina B., Bogacz A., 2016. Selected issues relating to classification of mountain organic soils in Poland according to the Polish Soil Classification 2011. Soil Science Annual 67(4): 185-189.

Glina B., Bogacz A., Gulyás M., Zawieja B., Gajewski P., Kaczmarek Z., 2016. The effect of long-term forestry drainage on the current state of peatland soils: A case study from the Central Sudetes (SW Poland). Mires and Peat 18(21): 1-11.

Glina B., Malkiewicz M., Mendyk Ł., Bogacz A., Woźniczka P., 2017. Human affected disturbances in vegetation cover and peatland development in the late Holocene recorded in shallow mountain peatlands (Central Sudetes, SW Poland). Boreas 46(2): 294-307.

Greinert A., 2015. The heterogeneity of urban soils in the light of their properties. Journal of Soils and Sediments 15(8): 1725-1737.

Hulisz P., 2007. Proposals of systematics of Polish salt-affected soils. Roczniki Gleboznawcze - Soil Science Annual 58(1/2); $1-10$.

Hulisz P., Kwasowski W., Pracz J., Malinowski R., 2017. Coastal acid sulphate soils in Poland: a review. Soil Science Annual 68(1): 46-54. 
Ibanez J.J., Boixadera J., 2002. The search for a new paradigm in pedology. [In:] Soil Classification 2001 (Micheli E., Nachtergaele F.O., Jones R.J.A., Montanarella L., Editors). ESBR Report No 7, EUR 20398 EN, Luxembourg: 93-110.

IUSS Working Group WRB, 2015. World Reference Base for soil resources 2014. International soil classification system for naming soils and creating legends for soil maps. Update 2015. World Soil Resources Report No. 106. FAO, Rome: $212 \mathrm{pp}$.

Jankowski M., 2013. Gleby ochrowe. Pozycja w krajobrazie, właściwości, geneza i miejsce w systematyce. Wyd. Nauk. UMK: 129 ss.

Jankowski M., Bednarek R., 2000. Quantitative and qualitative changes of properties as basis for distinguishing development stages of soils formed from dune sands. Polish Journal Soil Science 33(2): 61-69.

Jarnuszewski G., Meller E., 2018. Morphological and physical properties of dehydrated Holocene carbonate limnic deposits in post-bog areas of NW Poland. Journal of Ecological Engineering 19(1): 136-142.

Kabała C., 2018. Rendzina (rędzina) - Soil of the Year 2018 in Poland. Introduction to origin, classification and land use of rendzinas. Soil Science Annual 69(2): 63-74.

Kabała C., Gałka B., Łabaz B., Anjos L., de Souza Cavassani R., 2018. Towards more simple and coherent chemical criteria in a classification of anthropogenic soils: A comparison of phosphorus tests for diagnostic horizons and properties. Geoderma 320: 1-11.

Kabała C., Labaz B., 2018. Relationships between soil pH and base saturation - conclusions for Polish and international soil classifications. Soil Science Annual 69(4): 206-214.

Kabała C., Świtoniak M., Charzyński P., 2016. Correlation between the Polish Soil Classification (2011) and international soil classification system World Reference Base for Soil Resources (2015). Soil Science Annual 67(2): 88-100.

Kabała C., Waroszewski J., Bogacz A., Łabaz B., 2012. On the specifics of Podzols in mountain areas. Soil Science Annual 63(2): 55-64.

Kacprzak A., Drewnik M., Uzarowicz Ł., 2006. Rozwój i kierunki przemian węglanowych gleb rumoszowych na terenie Pienińskiego parku Narodowego. Pieniny - Przyroda i Człowiek 9: 41-50.

Kacprzak A., Migoń P., Musielok Ł., 2013. Using soils as indicators of past slope instability in forested terrain, Kamienne Mts., SW Poland. Geomorphology 194: 65-75.

Kalisz B., Łachacz A., 2008. Morfologia i systematyka gleb mułowych na przykładzie transektów w dolinie Omulwi i Rozogi. Roczniki Gleboznawcze - Soil Science Annual 59(3/ 4): 89-96.

Klasyfikacja gleb leśnych Polski, 2000. Centrum Informacyjne Lasów Państwowych, Warszawa: 127 pp.

Klasyfikacja uziarnienia gleb i utworów mineralnych Polskiego Towarzystwa Gleboznawczego 2008, 2009. Roczniki Gleboznawcze - Soil Science Annual, 60(2): 6-15

Kobierski M., 2013. Morfologia, właściwości oraz skład mineralny gleb płowych zerodowanych w wybranych obszarach morenowych województwa kujawsko-pomorskiego. Wyd. UTP, Bydgoszcz, 166: 121 pp.
Komisarek J., Szałata S., 2008. Zróżnicowanie uziarnienia w profilach gleb płowych zaciekowych z obszaru Wielkopolski. Nauka Przyroda Technologie 2(2): 10.

Konecka-Betley K., Czępińska-Kamińska D., Janowska E., 1996. Czarne ziemie w staroaluwialnym krajobrazie Puszczy Kampinoskiej. Roczniki Gleboznawcze - Soil Science Annual, 47(3-4): 145-158.

Kowalska J., Kajdas B., Zaleski T., 2017. Variability of morphological, physical and chemical properties of soils derived from carbonate-rich parent material in the Pieniny Mountains (south Poland). Soil Science Annual 68(1): 27-38.

Kowalska J. B., Zaleski T., Józefowska A., Mazurek R., 2019. Soil formation on calcium carbonate-rich parent material in the outer Carpathian Mountains-A case study. Catena 174: 436-451.

Kozłowski M., Komisarek J., 2017. Textural diversity in selected Retisols in the catena of the Opalenica Plain (western Poland). Soil Science Annual 68(1): 11-18.

Krasilnikov P., Martí J. J. I., Arnold R., Shoba S., 2009. A handbook of soil terminology, correlation and classification. Routledge, London, UK: 448 pp.

Krupski M., Kabała C., Sady A., Gliński R., Wojcieszak J., 2017. Double-and triple-depth digging and Anthrosol formation in a medieval and modern-era city (Wrocław, SW Poland). Geoarchaeological research on past horticultural practices. Catena 153: 9-20.

Lasota J., Błońska E., Pacanowski P., 2018. Forest sites and forest types on rendzinas in Poland. Soil Science Annual 69(2): 121-129.

Lemkowska B., Sowiński P., 2018. Limnic Rendzinas in the Mazurian Lakeland (NE Poland). Soil Science Annual 69(2): 109-120.

Ligęza S., 2016. Zmienność współczesnych mad puławskiego odcinka Wisły. Wydawnictwo UP w Lublinie, Lublin: 131 pp.

Łabaz B., Kabała C., 2014. Geneza, właściwości i klasyfikacja czarnych ziem w Polsce. Soil Science Annual 65(2): 80-90.

Łabaz B., Kabała C., 2016. Human-induced development of mollic and umbric horizons in drained and farmed swampy alluvial soils. Catena 139: 117-126.

Łabaz B., Musztyfaga E., Waroszewski J., Bogacz A., Jezierski P., Kabała C., 2018. Landscape-related transformation and differentiation of Chernozems - Catenary approach in the Silesian Lowland, SW Poland. Catena 161: 63-76.

Łachacz A., Nitkiewicz M., Pisarek W., 2009. Soil conditions and vegetation on gyttja lands in the Masurian Lakeland. [W:] Wetlands - their functions and protection (Lachacz A., Editor), Department of Land Reclamation and Environmental Management, University of Warmia and Mazury in Olsztyn: 61-94.

Marcinek J., Spychalski M., 1998. Degradacja gleb organicznych doliny Obry po ich odwodnieniu i wieloletnim rolniczym użytkowaniu. Zeszyty Problemowe Postępów Nauk Rolniczych 460: 219-236.

Mendyk Ł., Świtoniak M., Bednarek R., Falkowski A., 2015. Genesis and classification of the soils developed from the sediments of the former Oleszek mill pond basin (the Chełmińskie Lakeland, N Poland). Soil Science Annual 66(1): $29-35$. 
Miechówka A., Drewnik M., 2018. Rendzina soils in the Tatra Mountains, central Europe: a review. Soil Science Annual 69(2): 88-100.

Mocek A., 1978. Gleby o charakterze murszowym w otulinie Słowińskiego Parku Narodowego. Roczniki Gleboznawcze - Soil Science Annual 29(3): 175-202.

Mocek A., Owczarzak W., Tabaczyński R., 2009. Uziarnienie oraz skład mineralogiczny frakcji ilastej czarnych ziem Gniewskich. Roczniki Gleboznawcze - Soil Science Annual 60(3): 123-132.

Musielok Ł., Drewnik M., Stolarczyk M., Gus M., Bartkowiak S., Kożyczkowski K., Lasota J., Motak A., Szczechowska K., Watty M., 2018. Rates of anthropogenic transformation of soils in the Botanical Garden of Jagiellonian University in Kraków (Poland). Catena 170: 272-282.

Musztyfaga E., Kabała C., 2015. Lithological discontinuity in Glossic Planosols (Albeluvisols) of Lower Silesia (SW Poland). Soil Science Annual 66(4): 180-190.

Okruszko H., 1969. Powstawanie mułów i gleb mułowych. Roczniki Gleboznawcze - Soil Science Annual 20(1): 25-49.

Orzechowski M., Smólczyński S., Sowiński P., 2004. Przekształcenia antropogeniczne gleb obniżeń śródmorenowych Pojezierza Mazurskiego. Roczniki Gleboznawcze - Soil Science Annual 55(2): 311-320.

Piaścik H., Gotkiewicz J., 2004: Przeobrażenia odwodnionych gleb torfowych jako przyczyna ich degradacji. Roczniki Gleboznawcze - Soil Science Annual 45(2): 331-338.

Piaścik H., Łachacz A., 1990. Właściwości fizyczno-wodne i retencyjne gleb mineralno-murszowych, murszowatych i murszastych sandru mazursko-kurpiowskiego. Acta Acad. Agricult. Tech. Olst. Geod. Ruris Regulat. 20: 79-88.

Prusinkiewicz Z., 2001. Smolnice gniewskie-właściwości, geneza, systematyka. Roczniki Gleboznawcze - Soil Science Annual 52(1-2): 5-21.

Roj-Rojewski S., Walasek M., 2013. Katena gleb mułowo-madowych w okolicy Suraża w Dolinie Górnej Narwi. Soil Science Annual 64(2): 34-40.

Rząsa S., 1963. Geneza i ewolucja mineralnych gleb murszowych na terenie odwadnianym. Roczniki WSR w Poznaniu 18: $151-223$.

Skiba S., Komornicki T., 1983. Gleby organiczno-sufozyjne w Tatrach Polskich. Roczniki Gleboznawcze - Soil Science Annual 34(4): 113-122.

Systematyka gleb Polski, 2011. Roczniki Gleboznawcze - Soil Science Annual 62(3): 1-193.

Systematyka gleb Polski, 2019. Polskie Towarzystwo Gleboznawcze, Komisja Genezy Klasyfikacji i Kartografii Gleb. Wydawnictwo Uniwersytetu Przyrodniczego we Wrocławiu, Polskie Towarzystwo Gleboznawcze, Wrocław -Warszawa: $250 \mathrm{pp}$.

Soil Survey Staff, 2014. Keys to Soil Taxonomy, 12th ed. USDANatural Resources Conservation Service, Washington, DC: $633 \mathrm{pp}$.
Szymański W., Skiba M., Skiba S., 2011. Fragipan horizon degradation and bleached tongues formation in Albeluvisols of the Carpathian Foothills, Poland. Geoderma 167: 340 350.

Świtoniak M., 2014. Use of soil profile truncation to estimate influence of accelerated erosion on soil cover transformation in young morainic landscapes, North-Eastern Poland. Catena 116: $173-184$.

Świtoniak M., 2015. Issues relating to classification of colluvial soils in young morainic areas (Chełmno and Brodnica Lake District, northern Poland). Soil Science Annual 66(2): 57-66.

Świtoniak M., Kabała C., Charzyński P., 2016. Propozycja anglojęzycznych nazw jednostek Systematyki gleb Polski. Soil Science Annual 67(3): 103-116.

Świtoniak M., Mroczek P., Bednarek R., 2016. Luvisols or Cambisols? Micromorphological study of soil truncation in young morainic landscapes - Case study: Brodnica and Chełmno Lake Districts (North Poland). Catena 137: 583595.

Uggla H., 1976. „Rędziny” Pojezierza Mazurskiego. Roczniki Gleboznawcze - Soil Science Annual 27(2), 113-125.

Uzarowicz Ł., Kwasowski W., Śpiewak O., Świtoniak M., 2018. Indicators of pedogenesis of Technosol developed in an ash settling pond at the Bełchatów thermal power station (central Poland). Soil Science Annual 69(1): 49-59.

Uzarowicz Ł., Zagórski Z., Mendak E., Bartmiński P., Szara E., Kondras M., Oktaba L., Turek A., Rogoziński R., 2017. Technogenic soils (Technosols) developed from fly ash and bottom ash from thermal power stations combusting bituminous coal and lignite. Part I. Properties, classification, and indicators of early pedogenesis. Catena 157: 75-89.

Waroszewski J., Kaliński K., Malkiewicz M., Mazurek R., Kozłowski G., Kabała C., 2013. Pleistocene-Holocene coverbeds on granite regolith as parent material for Podzols - An example from the Sudeten Mountains. Catena 104: 161-173.

Waroszewski J., Sprafke T., Kabała C., Kobierski M., Kierczak J., Musztyfaga E., Łabaz B., 2019. Tracking textural, mineralogical and geochemical signatures in soils developed from basalt-derived materials covered with loess sediments (SW Poland). Geoderma 337: 983-997.

Waroszewski J., Sprafke T., Kabała C., Musztyfaga E., Łabaz B., Woźniczka P., 2018. Aeolian silt contribution to soils on mountain slopes (Mt. Ślęża, southwest Poland). Quaternary Research 89(3): 702-717.

Wasak K., Drewnik M., 2012. Properties of humus horizons of soils developed in the lower montane belt in the Tatra Mountains. Polish Journal Soil Science 45(1): 57-68.

Zagórski Z., 2003. Mineralogiczne i mikromorfologiczne wskaźniki genezy i właściwości rędzin wytworzonych ze skał węglanowych różnych formacji geologicznych. Fundacja „Rozwój SGGW": 245 ss.

Received: May 27, 2019

Accepted: July 24, 2019

Associated editor: J. Chojnicki 


\section{Systematyka gleb Polski, wydanie szóste - podstawy teoretyczne, schemat klasyfikacji i korelacje}

Streszczenie: Szóste wydanie Systematyki gleb Polski (SGP6) ma na celu ugruntowanie pozycji klasyfikacji gleb w Polsce jako nowoczesnego systemu naukowego, który odzwierciedla aktualny stan wiedzy naukowej, współczesne rozumienie funkcji gleb oraz potrzeby praktyczne, w tym związane z kartografią gleb. SGP6 kontynuuje tradycję ostatnich wydań systematyki przygotowanych pod auspicjami Polskiego Towarzystwa Gleboznawczego, w szczególności w zakresie konsekwentnego stosowania ilościowo zdefiniowanych poziomów, właściwości i materiałów diagnostycznych, ale zawsze odnoszących się do genezy i współczesnego przeobrażenia gleb. Definicja gleby - przedmiotu klasyfikacji - została zmodernizowana w odpowiedzi na współczesne potrzeby szerszego uwzględnienia (oraz właściwego nazwania) gleb stworzonych przez człowieka lub podlegających silnym przeobrażeniom pod wpływem człowieka. Zatem na potrzeby SGP6 gleba jest definiowana jako powierzchniowa część litosfery lub trwale powiązane z litosferą (za pośrednictwem budynków lub budowli) nagromadzenie części mineralnych i organicznych, pochodzących z wietrzenia lub akumulacji, naturalnej lub antropogenicznej, ulegające przeobrażeniu przy udziale czynników glebotwórczych oraz mające zdolność zaopatrywania organizmów żywych w wodę i składniki pokarmowe. SGP6 wyróżnia trzy hierarchiczne poziomy klasyfikacji: rząd (w łącznej liczbie 9), typ (podstawowa jednostka klasyfikacyjna; łącznie 30 typów) i podtyp (łaccznie 183 jednostki wyróżniane na podstawie 62 zdefiniowanych podtypów; podtypy są wymienione hierarchicznie, osobno w każdym typie), którym towarzyszą trzy niehierarchiczne poziomy klasyfikacyjne: odmiana (definiująca dodatkowe cechy pedo-, lito- lub antropogeniczne), rodzaj (definiujący rodzaj skały macierzystej) i gatunek (definiujący uziarnienie w profilu). Jednostki niehierarchiczne mają uniwersalne definicje, co umożliwia ich użycie w różnych rzędach/typach, jeśli tylko spełnione są wszystkie wymagania wymienione w definicji. Poniższy artykuł objaśnia podstawy teoretyczne, schemat klasyfikacji oraz zasady klasyfikacji gleb w SGP6, obejmuje klucz do rzẹdów i typów, tabele wyjaśniajaca zależności między poziomami, właściwościami i materiałami diagnostycznymi wyróżnianymi w SGP6 oraz w ostatnim wydaniu klasyfikacji międzynarodowej FAO-WRB, a także tabelę korelacji między SGP6 a WRB i Soil Taxonomy.

Słowa kluczowe: systematyka gleb, rząd gleb, typ gleb, geneza gleb, World Reference Base, Soil Taxonomy 